\title{
PODNIKANIE V RÉŽII ARISTOKRATA: ZALOŽENIE A PRVÉ ROKY SÚKENKY V UHROVCI (1845 - 1851)
}

\author{
EVA K O WA L S K Á
}

KOWALSKÁ, Eva. Business directed by an aristocrat: the establishment and first years of the textile factory at Uhrovec (1845-1851). Historický časopis, 2018, 66, 3, pp. 429-456, Bratislava.

The (Fein) Tuchfabrik at Uhrovec was established in a region that apparently lacked material and infrastructure pre-conditions. However, the project had another comparative advantage - the strong capital of the owner, a rich aristocrat with connections that enabled him to successfully establish himself in the economic space of Upper Hungary. Count Karl Zay was a supporter of liberalism and of progressive business aims such as railways and steam ships. The factory had various company shops and a network of customers across the Kingdom of Hungary. In the revolutionary period it began to profit from supplying the army, county units and the gendarmerie or police. However, state orders were also a risk factor in the form of unrealistic conditions from the side of customers, which gradually began to threaten the profitability of the business. At the beginning of this cooperation, the factory immediately began to make losses, which began to threaten its functioning.

The study analyses the process of establishment of the factory, the financial questions of building and equipping it, the questions of personnel and the material functioning as well as the social security of the workers, a large proportion of whom were women.

Key words: Kingdom of Hungary. Uhrovec. Karl Zay. History of manufacturing. Textile industry. $19^{\text {th }}$ century.

DOI: https://doi.org/10.31577/histcaso.2018.66.3.3

\section{...derselbe weder von den Erträgnissen der Fabrik zu leben, noch sich diesfalls fremden Ansichten zu unterordnen genöthigt ist... ${ }^{1}$}

Industrializácia Uhorska postupovala od začiatku 19. storočia len pomaly, s fázovým posunom oproti iným častiam Európy a aj ostatným častiam Rakúskej monarchie. Navyše sa vyznačovala výrazným špecifikom, ktoré do značnej mie-

1 Pressburger Zeitung 4. 4. 1845, s. 203. Dostupné online [cit. 2017-02-05]: http:// pc139.ulib.sk/search/i.jsp?pid=uuid:1ec30e40-d452-11de-8dc5-000d606f5dc6\#periodical-periodicalvolume-periodicalitem-page_uuid:9554a2f0-d5d0-11df-b1d2-000d606f5dc6 
ry ovplyvňovalo jej priebeh a podobu: spočiatku boli hlavnými protagonistami industrializácie príslušníci významných aristokratických rodov. ${ }^{2}$ Majitelia rozsiahlych pozemkových komplexov mali k dispozícii rôznorodé zdroje, ktoré mohli využit' aj v d'alších odvetviach a na dlhšiu či kratšiu dobu, v závislosti od rozličných okolností, dosiahnut' výraznú prosperitu. ${ }^{3}$ Ich majetkové pomery, rozsiahly systém privilégií a zároveň podiel na výkone politickej moci im umožňovali vstúpit' do priemyselného podnikania z výhodnejšej ,štartovacej čiary“, než mali príslušníci iných vrstiev, akokol’vek boli majetní. Svoje štandardné príjmy tak mohli l'ahšie obohatit' o výnosy z podnikania v rôznych odvetviach priemyslu. ${ }^{4}$ Vládou udržiavaný pol'nohospodársky charakter Uhorska a rozsiahly pozemkový fond prevažne $\mathrm{v}$ rukách šl'achty orientoval záujem podnikatel'ov na priemysel spracujúci pol'nohospodárske produkty. ${ }^{5}$

V rámci uhorskej šlachty, resp. aristokracie neboli rozsiahle majetkové komplexy, rozkladajúce sa navyše vo viacerých a typologicky úplne odlišných častiach Uhorska, ničím výnimočným. Aj ked' sa pri dedení často drobili, rozumne hospodáriacim a podnikavým majitel’om, aj pri využití vhodnej sobášnej politiky, dokázali poskytnút' dostatok zdrojov pre pohodlný spôsob života. Príkladom takéhoto využitia potenciálu vlastnej majetkovej podstaty a osobnostných predpokladov je sanácia a naštartovanie hospodárskeho vzostupu významného ma-

2 O podnikaní Andrássyovcov pozri LÖRINČÍKOVÁ, Silvia. Podnikanie aristokracie v oblasti baníctva a hutníctva v 19. storočí na príklade grófa Juraja Andrássyho. In Montánna história. Ročenka o dejinách baníctva a hutníctva. Limbach: Slovenská spoločnost' pre sociálne a hospodárske dejiny 2011, č. 3, s. 254-259. ISBN 9788097097301

3 Reprezentatívny príklad predstavoval rodový majetok Habsburgovcov, komplex Holíčsko-šaštínskeho panstva. K tomu ZEDINGER, Renate. Franz Stephan von Lothringen (1708-1765). Monarch, Manager, Mäzen. Wien; Köln; Weimar: Böhlau, 2008, s. 224-231. ISBN 3205781090; RAGAČ, Radoslav - FIALOVÁ, Ivana. Stopy hospodárskych aktivit Františka Štefana Lotrinského na cisárskom panstve Holíč. Bratislava: RRA Skalica, 2011. ISBN:9788097031732; ČERVENKOVÁ, Ivana. Panstvá cisára Františka Štefana Lotrinského v Šaštíne a Holíči ako príklad efektívne fungujúceho hospodárstva. In KUŠNIRÁKOVÁ, Ingrid a kol. „Pre blaho nášho l'udu, všetkých našich královstiev a provincii“. Reformná politika Márie Terézie a jej pokus o modernizáciu Uhorska. Bratislava: HÚ SAV, Veda 2016, s. 197-218. ISBN 9788015347; GEPP, Christian. Grundherrschaft Holíč - eine wirtschaftliche Betrachtung der Jahre 1735-1765. In KUŠNIRÁKOVÁ, „Pre blaho nášho l’udu,... “, s. 219-229. Nešl’achtici sa uplatnili istý čas v banskom podnikaní, najmä v spišsko-gemerskom revíre. Bližšie LACKO, Miroslav. Štátne financie habsburskej monarchie a uhorská med' v období vojny o rakúske dedičstvo. Štát kontra súkromní t’ažiari. In Historický časopis, 2015, roč. 63, č. 1, s. 3-26. ISSN 0018-2575.

4 ŠPIESZ, Anton. Manufaktúrne obdobie na Slovensku. Bratislava: Vydavatel'stvo SAV, 1961, s. 262-267.

5 VADKERTYOVÁ, Katarína. Dejiny cukrovarnickeho priemyslu a pestovania cukrovej repy na Slovensku (1800 - 1918). Bratislava: Veda, 1972. 
jetkového komplexu Zayovcov z Bučian a (Zay-) Uhrovca. Išlo o starobylý rod, ktorý získaním baronátu roku 1560 postúpil na rebríčku uhorskej šl'achty, aby potom $\mathrm{v}$ dôsledku striktného udržiavania luteránskej konfesijnej identity načas ustúpil z popredných miest v rámci politickej elity. ${ }^{6}$

$\mathrm{V}$ priebehu 18. storočia sa členovia rodu postupne prepracovali na rozhodujúce posty evanjelickej a. v. komunity v Uhorsku, aby sa v prvej polovici 19. storočia opät' zaradili medzi najvyššiu aristokraciu udelením grófskeho titulu (1830). Aj tento vzostup umožnil Karolovi Zaymu, aby dosiahol (podobne, ako jeho starý otec Peter) titul generálneho inšpektora cirkvi a zaujal popredné miesto medzi protagonistami reformného hnutia a revolúcie 1848. Jeho miesto však nebolo len na scéne politického a cirkevného diania: rovnako významný bol jeho prínos k rozvoju železnice a najmä textilného priemyslu, ktorý reprezentovala ním založená fabrika na súkno v Uhrovci.

Fabrika, vo svojej dobe nazývaná Ugroczer (Fein)Tuchfabrik, bola významná na celouhorskej úrovni, o to viac poznačila mikroregión, v ktorom pôsobila. ${ }^{7}$ Jej vznik a fungovanie počas celej existencie boli už predmetom všeobecného spracovania, ${ }^{8}$ bohatý archívny fond sa však priam ponúka na analytický pohl'ad: preto sa $\mathrm{v}$ tejto štúdii sústredím na najzaujímavejšie obdobie, za aké považujem roky od vzniku do začiatku 50. rokov. Počas nich sa majitel', riaditel'stvo a osadenstvo súkenky muselo vyrovnat's procesom stavby budov továrne, jej zariad'ovaním, rozbehom výroby a podnikania, aj so zložitým obdobím počas búrlivých revolučných rokov a hl'adaním stálych odberatel'ov.

V priebehu niekol'ko málo rokov sa dá do najmenších detailov sledovat' proces vzniku podniku ,na zelenej lúke“, kroky k dosiahnutiu optimálnej produkcie a zisku, analyzovat' význam štátnych objednávok aj podiel domácich a cezpol'ných na jeho úspechoch i neúspechoch. Podnik môže slúžit' ako príklad podnikatel'ského zámeru realizovaného v nie celkom typicky industriálnom prostredí a dokonca mimo hlavných komunikačných trás - o to viac je zaujímavé sledovat', ako bolo možné prekonat' problémy, ktoré sa mu stavali do cesty.

6 Kolektívnu biografiu rodu spracovala najnovšie FUKÁRI, Valéria. Felsö-magyarországi föúri családok. A Zayak és rokonaik 16-19. század. Pozsony: Kalligram, 2008. ISBN 9788071499718.

7 Inak kvalitne spracovaná monografia obce venuje továrni len obmedzenú pozornost', pričom autori si všimli najmä technické aspekty výroby: ŠIŠMIŠ, Milan - BEŠTOVÁ, Elena - KVASNICOVÁ, Ol'ga. Uhrovec. Uhrovec: Obec Uhrovec, 2007, s. 44. ISBN 9788096966813.

8 KRAJČOVIČOVÁ, Klára: Továreň na súkno v Uhrovci (1845 - 1873). In Zborník SNM, 1972, roč. 66, História 12, s. 135-164; staršie spracovanie SZTUDINKA, Ferenc. Gróf Zay Károly zay-ugróczi volt posztógyárának története (1845-1872) (=Magyar ipartörténet, III). Budapest 1909. 


\section{Majetková podstata Zayovcov z Uhrovca a Bučian}

Prvú viditel'nú stopu uhroveckej súkenky v dejinách podnikania možno vidiet' v zverejnení inzerátu v čísle Pressburger Zeitung zo 4. apríla 1845, v ktorom sa avizovalo blízke otvorenie súkenky. Jednoznačným spôsobom sa v ňom dával najavo podnikatel'ský zámer majitel'a schopného uviest' do chodu vlastný kapitál a pomôct' nielen svojmu vlastnému rozpočtu, ale aj rozvoju celej vlasti. ${ }^{9}$ Pochopitel'ne, to už prebiehali stavebné a organizačné aktivity, ktoré mali pomôct' tieto ciele zhmotnit' v podobe novej, moderne zariadenej budovy, vybavenej zahraničnými strojmi a obsadenej zamestnancami z blízkeho okolia aj vzdialenejších lokalít.

Prehistória podniku, symbolizujúceho modernizačné trendy, sa dá vystopovat' vo vývoji zayovského majetkového komplexu už v poslednej tretine 18. storočia. To sa pomerne stabilizovaný majetok baróna Petra Zayho, zložený zo základného dedičného podielu (panstvo Uhrovec) a d'alších častí, ktoré do rodového ,portfólia“ pribudli vd’aka jeho manželkám, dostal do vážnych problémov. Prvá a tretia manželka Petra Zayho, Eleonóra a Ludovika (Lujza) Amália, obe rodené Kalisch (Calisius, Kališ, podl'a rodového sídla Kalisz v Pol'sku) priniesli ako veno nárok na majetky v Malých Bierovciach a Bytčici, ale aj Sobotišti a Skalici. Druhá manželka Mária Francisca bola síce príslušníčkou významného ríšskeho rodu grófov Auerspergovcov, no svokor ako dôstojník napriek tomu nedisponoval príliš vel'kým majetkom. Peter Zay mohol teoreticky získat' dispozičné práva na aspoň čast' majetku svokrovcov (vlastníctvo domu v Šoprone), ale napäté, ba až nepriatel'ské vzt'ahy so svokrovcami, o to viac smrt' manželky, komplikovali či lepšie povedané zhatili tieto predstavy. Faktickým dedičom Auerspergovcov sa stal Petrov syn Imrich Richard. ${ }^{10}$

Petrovi Zaymu, ktorý mal a od roku 1758 aj realizoval ašpirácie na významné postavenie v evanjelickej cirkvi a. v., majetok koncentrovaný na zatial' nie vel'mi významný Uhrovec a $\mathrm{k}$ nemu patriace panstvá príliš nevyhovoval. Pôvodným sídlom rodu bol už v 18. storočí schátraný stredoveký hrad, ${ }^{11}$ respektíve kaštiel', no jedna jeho čast' (krídlo) patrila rodine katolíka Ladislava Kollonicha, rodeného Zay. Jeho sobáš s príslušníčkou významného rodu, konverzia ku katolicizmu a následná adopcia viedenským biskupom bola klasickým príkladom úsilia o zachovanie rodového majetku vymierajúcich Kollonichovcov. Vel'ký osoh ne-

9 Ref. 1.

10 Dedičstvo mu pripadlo až po roku 1800. Petrovi Zaymu sa narodilo šest' synov a dcéra, dospelosti sa však dožil len Žigmund a Imrich, cez ktorého rodová línia pokračovala d’alej. Pozri aj FUKÁRI, ref. 6.

$11 \mathrm{~K}$ vývoju vlastníckych vzt’ahov vo vzt’ahu $\mathrm{k}$ hradu pozri JANKOVIČ, Vendelín. Z dejín Uhrovca a tamojšieho kaštiel'a. In Monumentorum tutela. Ochrana pamiatok XI. Bratislava: Obzor pre ŠÚPS, 1984, s. 15-31. 
prinášala ani mestská kúria v Skalici, ktorá sa do rodového portfólia Zayovcov dostala cez podiel na dedičstve Calisiovcov (Kališovcov) ${ }^{12}$ a bola ponechaná v prenájme: jeho podmienky boli tak nejasné, že pri vysporiadaní majetku začiatkom 19. storočia sa len s námahou zist'ovalo skutočné vlastníctvo domu. ${ }^{13}$

Uvedené komplikované majetkové pomery bezpochyby neposkytovali dostatočné predpoklady pre reprezentáciu politicko-cirkevného významu funkcie generálneho inšpektora a hodnosti komorského radcu, ktorú Peter Zay získal. Podl'a autentického vyjadrenia Petrovho syna Imricha to bola jeho macocha posledná Petrova manželka, ktorá iniciovala nákup rozsiahleho panstva a kaštiel’a v Bučanoch. Majetok na úrodnej pôde a blízko obchodných a spoločenských centier napriek tomu znamenal neúmerné bremeno - bol zakúpený na úver a aj prevádzka vel'kého sídla bola finančne náročná. $\mathrm{O}$ to viac, že medzi rodové majetky pribudol neskôr aj majetkový podiel jej brata, ktorý presídlil zo Sliezska do Viedne. ${ }^{14}$ Ťažké finančné straty predstavovali aj požiare v rôznych poddanských obciach: len r. 1786 napáchali škodu za 10-tisíc zlatých. ${ }^{15}$ Dostat' sa z dlhov teda predpokladalo intenzívne sa venovat' hospodáreniu, to však Peter Zay v pozícii generálneho inšpektora evanjelickej a. v. cirkvi z objektívnych príčin nevládal. V dobe príprav Tolerančného patentu aj po jeho vydaní bol konfrontovaný s množstvom úloh, ktoré si realizácia patentu vyžadovala. ${ }^{16}$ Pohyboval sa medzi Viedňou, Prešporkom, Budínom a Peštou a v Bučanoch sa zdržiaval nepravidelne. Dôsledky sa dostavili vel'mi rýchlo: už koncom 80. rokov sa jeho syn Imrich obával, že v budúcnosti spolu s mladším bratom Žigmundom s Bučanmi zdedí len dlhy, o to viac, že macocha bola zlou (či skôr l'ahkovážnou) hospodárkou. ${ }^{17}$ Navyše, práve Žigmund bol po matke predurčený na dedenie Calisiovských majetkov a teoreticky mohol získat' nad bratom prevahu. Imrich, ktorého nelákali vyhliadky na východisko v podobe nejakého namáhavého a nedostatočne plate-

12 Calisiovci/Kalischovci boli viacnásobne spríbuznení so Zayovcami od 18. storočia. Pozri FUKÁRI, ref. 6.

13 Správu tohto domu, pokial' bol v priamom užívaní Kalischovcov, vykonával Ján (Johann) Hajny - Hajnóczi, starý otec Jozefa Hajnóczyho. Bližšie KOWALSKÁ, Eva - KANTEK, Karol. Uhorská rapsódia alebo Tragický osud osvietenca Jozefa Hajnóczyho. Bratislava: Veda, 2008, s. 34-36. ISBN 9788022410342.

14 List Imricha Zayho starej matke Auerspergovej z 25. 5. 1785. SNA, Fond Zay, Bučiansky archív, Imrich Zay - Korešpondencia, kartón (d’alej k.) 100, 3. čast', fol. 184-185.

15 SNA - Fond Zay, Bučiansky archív, Imrich Zay - Korešpondencia, k. 100, 2. čast', fol. 118121.

16 Bližšie k tomu KOWALSKÁ, Eva. Evanjelické a. v. spoločenstvo v 18. storočí. Hlavné problémy jeho existencie a fungovania v spoločnosti. Bratislava: Veda 2000, s. 132-134. ISBN 8022407046.

17 Vyjadrenie Imricha Zayho v liste svojej tete z 1.3.1789. SNA, Fond Zay, Bučiansky archív, Imrich Zay - Korešpondencia, k. 101, 2. čast', fol. 8-9. 
ného úradníckeho postu, sa preto na nevôl'u rodičov rozhodol pre dávno vysnívanú vojenskú kariéru, ktorá mu podl'a vlastných slov sl'ubovala dôstojný život aj bez zázemia vel'kého majetku a čestnejšie vzt'ahy medzi l'ud'mi. ${ }^{18}$ Pomerne skorá otcova smrt' r. 1788 mu dala za pravdu: riadenia majetku sa ujala jeho vdova, ktorá panstvá v Bučanoch aj Uhrovci d’alej zadlžovala. Kritický postoj $\mathrm{k}$ nevlastnej matke vyústil do úplného odcudzenia voči nej a občasných úvah Imricha o definitívnom odchode z Uhorska.

Paradoxne, dobový rešpekt $\mathrm{k}$ vôli rodičov (aj ked' práve napriek ich odporu vstúpil do armády) úplne zmenil osud Imricha Zayho a rodového majetku. Imrich totiž vážne pomýšl'al na sobáš s bližšie nemenovanou ženou v mieste dislokácie svojej jednotky v habsburskom Nizozemsku (v Liége). Macocha si bola dobre vedomá, že by to $\mathrm{v}$ budúcnosti mohlo skomplikovat’ riešenie majetkových záležitostí a pohotovo mu avizovala vhodnejšiu partiu - svoju neter, dcéru Johanna Traugotta Calisia (Kalischa), Máriu Alžbetu Helenu (Mimi). Tento krok mal št’astné vyústenie nielen v rýchlom vzplanutí vzájomnej náklonnosti, uzavretí manželstva (aj za cenu vystúpenia $\mathrm{z}$ armády), ale aj v naštartovaní konsolidácie zayovského rodového majetku. S nevestou sa viazal príslub značného vena (obligácie spolu za 72000 zlatých), hoci k jeho vyplateniu došlo až po smrti jej matky (1799). Väčšinu z neho (40 000) investovali do splatenia dlhov zat'ažujúcich majetok v Bučanoch. ${ }^{19}$ Majetok však pomohli zachránit' a zvel'adit' aj pokonania v rámci rodiny: predčasné úmrtie brata Žigmunda (1806) znamenalo vyrovnanie sa s macochou. ${ }^{20}$ Hoci Imrich musel krátko po sobáši vynaložit' takmer 10000 zlatých na náklady insurekcie a sanovat' nemalé škody spôsobené opät' požiarmi, ${ }^{21}$ uvol'nili sa mu ruky na naštartovanie podnikania. Najskôr sa od r. 1810 sanovalo hospodárenie na majetku v Bučanoch, kde Imrich začal s vylepšovaním infraštruktúry a hospodárenia (úprava vodných tokov, mlyna); vhodné zariadenia sa dali do prenájmu (mlyn v Bučanoch, 1821). Do poriadku sa dali aj nejasné majetkové väzby na mestskú kúriu v Skalici, ktorá bola v právne

18 Vojenskú kariéru I. Zayho analyzuje štúdia KOWALSKÁ, Eva. Dôstojník v armáde a spoločnosti na prelome 18. a 19. storočia: Imrich II. Zay a jeho kariéra (1765 - 1831). In Vojenská história, 2015, roč. 19, č. 2, s. 147-160. ISSN 1335-3314.

19 Bučiansky majetkový podiel Imricha Zayho bol pri delení majetku v dobe jeho sobáša r. 1796 zat’ažený dlhom vo výške 118123 zl. SNA, Fond Zay, Bučiansky archív, Karol Zay, No. 1-156, k. 193, fasc. 1-155, fol. 258-259.

20 Ich vzt’ah sa napriek tomu nezlepšil a barónka určila za generálneho dediča svojho majetkového podielu prešporský evanjelický a. v. konvent.

21 Krátko po sobáši mladým Zayovcom zhoreli budovy pri kaštieli v Uhrovci následkom požiaru v ned’alekej pálenici. Podobne v máji 1800 následkom búrok horeli domy vo viacerých lokalitách bučianskeho panstva (Podolie, Vrbové, Častkovce). SNA, Fond Zay, Bučiansky archív - Karol Zay, k.193, fasc. 1-155, fol. 278-279. 
nepodloženom nájme grófa Jozefa Gvadányiho ${ }^{22}$ a po vysporiadaní r. 1815 bola nanovo dlhodobo prenajatá. ${ }^{23}$ Zayovský majetkový komplex najviac narástol po smrti posledného Kollonicha (generála Maximiliána Kollonicha, †1827), ked’ Karol Zay r. 1833 získal jeho podiel na uhroveckom kaštieli a panstve. Odvrátenou stranou tejto akvizície bola nutnost' prebrat' enormné dlhy, ktoré bolo treba umorovat' z výnosov iných majetkov.

Vzmáhat' sa začalo aj panstvo v (Zay-) Uhrovci, ktoré bolo dlhý čas akoby $\mathrm{v}$ druhoradom postavení v porovnaní s potenciálne a napokon aj reálne lukratívnejšími Bučanmi. Bučany začali vynášat' podstatne viac a poskytovali aj väčší komfort pre život aristokratickej rodiny: ležali takpovediac na okraji chotára Trnavy, nehovoriac o blízkosti železnice, ktorá od konca 40. rokov začala byt' významným faktorom hospodárskeho rozvoja. Nebolo z nich d'aleko do Prešporka, Viedne ani Šoprone. Práve v Šoproni rodina vlastnila dom po starých rodičoch Auerspergovcoch, v ktorom Imrich krátko v počiatkoch manželstva býval a kde strávil prvé školské roky aj jeho syn Karol. Uhrovec bol prít’ažlivý najmä v lete: po roku 1814 sem pravidelne chodili na návštevy prominentní hostia z Viedne (literáti Caroline Pichler a Franz Grillparzer, vysokí dôstojníci) a domov (a k tomu apanáž) tu našla po niekol'ko rokov aj v tej dobe známa poetka Theresia Artner. ${ }^{24}$ Hoci obec a okolie boli malebné, celé pril'ahlé panstvo príliš nevynášalo: ročný zisk do roku 1808 predstavoval menej než 5000 zlatých. Uhrovecká dolina nebola príliš vhodná na rastlinnú produkciu, zato však oplývala lesmi a poskytovala podmienky aj pre chov oviec. Práve cez chov oviec na vlnu, čo bola počas konjunktúry v dobe insurekcií, vojen s Napoleonom a rozkolísaných klimatických pomerov pomerne obvyklá stratégia pre vylepšenie príjmov, ${ }^{25} \mathrm{sa}$ stav uhroveckých financií začal stabilizovat' a zisk narástol v rokoch 1809 - 1813 na cca 10 - 11000 zl. Aby sa vlna mohla zužitkovávat' v mieste produkcie, panstvo dalo roku 1813 zriadit' novú valchu a dohodlo sa so súkenníckymi majstrami v Uhrovci, že ju budú počas troch rokov používat' za nevysoký nájom (100 zl. ročne v štyroch splátkach) ${ }^{26}$

22 K tomu SNA, Fond Zay, Bučiansky archív - Rôzne, Imrich a Karol Zay, k. 116, fasc.4, fol. 14-15.

23 Nájomná zmluva v SNA, Fond Zay, Bučiansky archív - Rôzne, Imrich a Karol Zay, k. 218, fasc. 9, fol. 102.

24 JÓNÁSOVÁ, Anna. Literárny salón - spôsob literárnej komunikácie v 17. - 19. storočí. Pokus o otvorenie literárnohistorickej témy. 2. čast'. In Knižnica, 2011, roč. 12, č. 5, s. 45- 48.

$25 \mathrm{Ku}$ prírodnej katastrofe r. 1815 HOLEC, Roman. Ako človek prestával byt' vládcom prírody. In Forum Historiae, 2017, roč. 11, č. 1. ISSN 1337-6861. Prehl'ad zakladatel'ských počinov z daného obdobia prináša ŠPIESZ, Anton. Manufaktúrne obdobie na Slovensku 1725 - 1825. Bratislava: Vydavatel'stvo SAV, 1961, s. 177-200.

26 SNA, fond Zay, Prefekt - Inšpektor panstiev, Hospodárske účty, Uhrovecké panstvo, rôzne Protokoly kontraktov, k. 406, č. 38, fol. 15. 
Je pozoruhodné, ako dokázal Imrich Zay zachránit' a povzniest' majetok, zat'ažený rôznymi dlhmi, aj bez zodpovedajúceho vzdelania. Jeho univerzitné štúdium v Lipsku totiž nebolo príliš intenzívne a značný čas mu zaberali aktivity spojené so zdokonal'ovaním sa v ,šl'achtických umeniach“ (jazda na koni, šermovanie). Aj väčšina jeho ponôs adresovaných domov rodičom sa týkala nedostatku peňazí, ktorý mu znemožňoval „stavu primeraný“ študentský život, teda skôr návštevu spoločnosti a divadla, ako posluchární a knižnice... Spoločnost', v ktorej sa pohyboval (zvlášt' priatel'stvo so synom cisárskeho generála Dagoberta Sigmunda Wurmsera, Christianom) a nejasné vyhliadky na budúce uplatnenie a najmä zabezpečenie ho už po dvoch rokoch v Lipsku priviedli do armády. Realizoval tak svoju od detstva pestovanú „,náchylnost’ $k$ vojenskému stavu“ "27 a dlhotrvajúci odpor voči „ekonomickému“ a civilnému stavu. So svojou jednotkou prežil bojové nasadenie pri obliehaní Belehradu, ale aj dislokáciu v rakúskom Nizozemsku, kde mal možnost' pozorovat' usporiadanie a fungovanie progresívne sa rozvíjajúcej spoločnosti.

Listy Imricha Zayho domov obsahujú aj postrehy o vyspelosti Antverp a Brabantska a za obdobu študijnej cesty za poznaním možno považovat' aj jeho ilegálny výlet do Londýna. Ked’že sa s týmto cudzím prostredím konfrontoval už ako zrelý muž, aj krátky pobyt vnímal ako podnet pre nadobúdanie skúseností a intenzívne pozorovanie. Nezostal však len pri čerpaní z týchto nie vel'mi systematicky nadobudnutých vedomostí: do svojej knižnice zarad'oval aj odborné diela z ekonómie či pol'nohospodárstva, vrátane Fándlyho, objednával si takto orientované časopisy a listy si vymieňal s uznávanými autoritami ekonomickej teórie (rakúsky ekonóm Franz gróf von Enzenberg, Johann Friedrich Mayer). Imrich dokázal ocenit’ aj hospodársky potenciál nových vynálezov a inovácií. Usiloval sa o aplikovanie novej technológie výroby cukru, ${ }^{28}$ pol'nohospodárskych strojov, pestovanie rýchlo rastúcich drevín (agátov) a vel'ký rozvoj očakával aj v oblasti dopravy: ako jeden z prvých si zaobstaral dve akcie Dunajskej paroplavebnej spoločnosti (Donau-Dampfschiffahrts-Gesellschaft) v hodnote dvesto guldenov. ${ }^{29}$ Imrichovo úsilie nezostalo bez úspechu a už počas svojho ži-

27 Spomína ju ako výraznú vo svojej korešpondencii a dosvedčuje ju aj pozostalost' viažuca sa na jeho detské roky. SNA, fond Zay, Bučiansky archív, Imrich Zay - Korešpondencia, k. 100, 3. Čast'.

28 Už r. 1811 podnikal pokusy s výrobou cukru z cukrovej repy podl'a metód Hermbstädta a Acharda. SNA, fond Zay - Korešpondencia, k. 136, fasc. 2, fol.4. Opieral sa pravdepodobne o ich diela HERMBSTÄDT, Sigismund Friedrich. Anleitung zur praktisch-ökonomischen Fabrikation des Zuckers, und eines brauchbaren Syrups aus den Runckelrüben. Berlin 1811 a ACHARD, Franz Carl. Die Zucker- und Syrups-Fabrication aus Runckelrüben. Breslau 1811. Porovnanie oboch metód bolo publikované profesorom K. A. Neumannom v Journal für Chemie und Physik, zv. 4, 1812, s. 259-303 a 348-361.

29 K 15. 7. 1821 bolo vydaných 1000 akcií v nominálnej hodnote sto guldenov, do predaja sa ich 
vota dokázal rodový majetok nielen zachránit', ale aj vymanit' z dlhov a položit' základy pre neskoršiu expanziu do d’alších sfér podnikania.

V otcových šlapajach sa vydal aj jeho syn Karol (12. február 1797 - 8. október 1871). Istú mieru podobnosti s otcovou životnou dráhou možno vidiet' už $\mathrm{v}$ tom, že neabsolvoval systematické vysokoškolské vzdelávanie a na typ kariéry, pre ktorú bol „,predurčený“, mu postačilo aj absolvovanie Král'ovskej akadémie v Prešporku. ${ }^{30}$ Ani v jeho prípade nešlo o klasické „zamestnanie“, ale skôr o výkon funkcií spojených s aktuálnymi povereniami (komorský radca, 1827). V dobe cholery $(1830$ - 1831) napríklad organizoval z postu komisára sanitárne opatrenia.

Neskôr sa angažoval ako nezávislý žurnalista (či skôr pravidelný prispievatel' do rôznych uhorských aj nemeckých novín) a politik (napr. ako člen snemovej komisie pre otázky banského podnikania, 1830), pričom najvýznamnejším postom bola od roku 1840 pozícia generálneho inšpektora evanjelickej a. v. cirkvi. Pre aristokrata jeho rangu bola obligátnou pravidelná účast' na zasadaniach Kasína (v Trnave mu predsedal od 13. januára 1839, vo výbore pôsobil aj v Pešti), rokovaniach snemu, aj príklon $\mathrm{k}$ myšlienkam národného ekonomického protekcionizmu a liberálneho hnutia.

Jeho záujmy nezostávali len v teoretickej rovine: zvažoval ponuku na funkciu v predstavenstve či priam vedenie účastinnej spoločnosti, ktorá by mala na starosti oživenie textilnej fabriky v Šaštíne. ${ }^{31}$ Už z domu mal v otcovi vzor racionálne a úspešne hospodáriaceho aristokrata, takže po jeho nečakanej smrti 18. augusta $1831^{32}$ sa podujal realizovat' podnikanie vo väčšom rozsahu. Inšpirácie mohol pritom čerpat' nielen $\mathrm{z}$ teoretickej literatúry: $\mathrm{v}$ danej dobe populárny a oceňovaný Friedrich List bol v Uhorsku nielen čítaný, ale aj počúvaný - v Prešporku odznelo napr. viacero jeho prednášok a priamo či nepriamo podnietil zakladanie akciových spoločností. ${ }^{33}$

dalo 500 a do konca novembra 1822 sa z nich predalo 232. Imrich mal akcie č. 43 a 44, desat' akcií pritom kúpil prvý investor Johann von Szallopek. SNA, fond Zay - Bučiansky archív, Imrich Zay - korešpondencia, k. 111, Fasc. I, fol.146-153.

30 NOVÁK, Veronika M. A pozsonyi jogakadémia hallgatósága 1777-1849. Budapest: MTA Egyetemtörténeti Albizottsága: ELTE Levéltára, 2007, s. 244, ISBN 9789634638988.

31 List Rudolfa Puthonyho z 20. 5. 1845 s príslušnou ponukou. SNA, fond Zay - Bučiansky archív, Karol Zay-Korešpondencia, k. 138, fasc. 14, fol. 216-217.

32 Imrich Zay zomrel krátko po získaní významného ocenenia svojich zásluh v podobe povýšenia do grófskeho stavu (12. 11. 1830) na následky cholerovej nákazy, ked’ nevenoval pozornost' prvým príznakom choroby a podcenil jej liečbu.

33 HOLEC, Roman. Fridrich List, Ochranný spolok a Slovensko. In Studia Historica Nitriensia VII. Nitra 1998, s. 97-126. K zakladaniu akciových spoločností pozri nasledujúcu poznámku. 


\section{Otázka finančného a materiálneho zabezpečenia podnikatel'ského záme- ru}

Založit továreň, o to viac v lokalite, akou je Uhrovec, muselo byt' bezpochyby spojené s vysokou mierou rizika. Podstupovali ho rovnako tí, čo mali dostatok vlastného vstupného kapitálu, ako aj tí, čo ho získavali až po zverejnení podnikatel'ského zámeru. Bankový úverový systém bol v Uhorsku len v počiatkoch, a tak sa neraz využila dost' neistá cesta vydávania a upisovania akcií - ako napr. v Kőszegu, Rábe (Győri) alebo Levoči, kde v rovnakom čase ako v Uhrovci plánovali rozbehnút' manufaktúru na súkno. ${ }^{34}$ Karol Zay sa touto cestou nemusel vydat': ešte pred zverejnením avíza o otvorení fabriky mal k dispozícii 241000 zl. konvenčnej meny, ktoré už v priebehu roka 1844 vkladal do jej pokladnice v trinástich splátkach. Do fabrickej pokladnice vkladal prostriedky aj neskôr, zväčša podl'a potreby a vlastných možností: roku 1846 to bolo 56790 zl. k. m., roku 1847 poskytol dočasný vklad 21000 zl. k. m., z ktorých si neskôr vyzdvihol $6 \%$ úrok. ${ }^{35}$ Nebol však jediný, kto investoval čast' svojich vol'ných financií do podniku. Fabrický fond slúžil ako istá forma sporitel'ne ${ }^{36}$ a svoje úspory mu v počiatočnom období poskytli aj B. Gudenam, evanjelický cirkevný konvent v Prešporku, istý pán Gyöngyély, Magdaléna a Mathias Stanzelovci či von Forster (spolu sa im za rok 1845 vyplatilo na úrokoch 2494 zl.10 gr. k. m.). Tento príklad nasledoval aj profesor Wilhelm Schimko, ktorý poskytol na kratšiu dobu 5000 zl. k.m., aby si potom celú sumu vybral spolu s úrokom takmer $80 \mathrm{zl}$. k. m. Vklady do fondu pribúdali aj neskôr, najviac od K. Zayho, ktorý podl'a svojich možností navyšoval kapitál nemalými sumami: v priebehu roku 1846 to bolo 56790 zl. k. m., v marci 1847 vložil d’alších 21000 zl. k. m. Aj on však zvykol vnímat' tieto úložky ako formu pôžičky a niekedy si vyberal obvyklý $6 \%$ úrok, v problematických obdobiach sa však výplaty úrokov zriekol.

Nadobudnutý kapitál až do nábehu výroby pochopitel'ne neležal umítvený: uhrádzali sa z neho potrebné výdavky (vrátane poplatkov za poistenie vznikajúcej fabriky), ktoré ku koncu roku 1845 dosiahli hodnotu 213463 zl. k. m. Čast' kapitálu sa kvôli získaniu úrokov uložila do pokladnice Indrustrie und Handels Verein v Pešti (2 000 zl. k. m.), resp. do sporitel'ne (cca 4500 zl. k. m.). Výdavky

34 Podl'a avíza v Pressburger Zeitung z 13. 12. 1844 sa o fabrike v Levoči rokovalo 3. 12. 1844. Podl'a správy uverejnenej tamže, 5. 5. 1845 organizačný výbor plánoval vydat' 1500 akcií po sto zlatých k.m., a až po predaji 800 kusov sa malo začat's realizáciou projektu. Avízo o fabrike, iniciovanej mešt’anmi 28. 10. 1844 v Köszegu tamtiež, 9. 12. 1844 a 13. 1. 1845; avízo o založení akciovej spoločnosti pre fabriku v Rábe tamtiež, 23. 4. 1845.

35 SNA, fond Zay - Súkenka, Účtovné knihy, Cassa-Buch 1846-1850, k. 578: Prima-nota Buch der Zay-Ugroczer Tuch Fabrik für das Jahr 1846.

36 V prípade Rábu, Kőszegu aj Levoče sa v mestách ustanovili samostatné pobočky sporitel'ne. Informácie o nich zverejňovali Pressburger Zeitung spolu s avízami o podnikatel’ských zámeroch. Pozri pozn. 34. 
dosiahli ku koncu roku 1845 spolu 213463 zl. 07 gr. k. m., a v účtovnej knihe sa vykázal celkový zisk 30071 zl. 20 grajciarov k. m.

Zay mal na jednej strane okrem vstupného kapitálu k dispozícii aj vhodný pozemok a d’alšiu potrebnú infraštruktúru: $v$ regióne sa mohol t'ažit' potrebný stavebný kameň, hlina a piesok, dostatok vody predurčil pre pohon viacerých zariadení prevádzkovo lacnejšiu vodnú silu, nehovoriac o vlastnej produkcii vlny. Na druhej strane však výrazným negatívom bola odl'ahlost' regiónu, ktorý ležal bokom od dôležitých komunikácií a dokonca bol odrezaný aj od poštových ciest: od Prešporku ho delilo pätnást' poštových staníc, najbližšia bola v Trenčíne, aj tam však cesta ešte i koncom 40. rokov trvala štyri hodiny. Bližšie položená poštová stanica $\mathrm{v}$ Bánovciach bola otvorená až 16. apríla 1850, čo zrýchlilo aspoň listový a peňažný styk. V Uhorsku sa o stavbe železnice začalo uvažovat' až v 40. rokoch, železničné kol'aje sa však Uhrovcu na dlhý čas zd'aleka vyhli. Spojenie s miestami odbytu produkcie, aj dodávanie surovín a strojov sa muselo realizovat' formou povozov. Tieto dial'kové fúry organizovali najmä miestni a bánovskí židovskí „transportéri“ či skôr dopravné firmy (Israel Kacser, Ksinan). Na cestách bolo pravidelne viacero povozníkov, ktorí zabezpečovali fúry do Pešti a do Prešporku, kde sa nakladal alebo vykladal tovar dodaný lodnou (a neskôr železničnou) dopravou. Druhá línia transportov smerovala do Uherského Hradišt’a, kde končila jedna z vetiev Severnej železnice (Nordbahn). Cez tento uzol sa dovážali najmä stroje, farby a chemické suroviny z rôznych nemeckých miest a Rakúska.

Odkázanost' fabriky na cestnú dopravu sa už v danej dobe ukázala byt' značnou nevýhodou: náklady na dodávku tovarov tvorili vel'ké sumy, ktoré sa pri danom spôsobe dopravy už nedali d’alej redukovat'. Výdavky na dodávky tovarov len do Pešti sa za roky 1848 a 1849 vyšplhali do výšky 12439 zl. k. m., pričom práve tento smer obchodných spojení už mohol využívat' kombinovanú lodnú a železničnú dopravu. Fabrika preto uprednostňovala stálych odberatel'ov, ktorí si objednávali (a zväčša z najbližšieho fabrického obchodu aj sami odvážali) tovar podl'a svojich požiadaviek. Najmä pre nich mali mimoriadny význam peštianske svätojánske trhy, ktoré slúžili na uzatváranie kontraktov. Výrobu aj distribúciu však poznamenala situácia na cestách panujúca v politicky rozbúrenom čase. Nielenže sa prejavil nedostatok pracovných síl, ale furmanov najmä od leta 1848 odrádzala od dlhých ciest neistota na cestách a správy o „rebeloch“.

Bezpochyby hlavným predpokladom pre úspech podnikatel'ského zámeru však bolo zabezpečenie strojov, prostredníctvom ktorých sa mohol realizovat'. Rokovania o ich dodávkach prebiehali už od februára 1845. Platby za stroje len do konca toho istého roku dosiahli $55574 \mathrm{zl}$. k. m. ${ }^{37}$ Zay vsadil na ich dodávate-

37 Finančný výkaz Geldrechnungen des Zay Ugroczer Tuchfabrik's Fondes von beginnungs 
l'ov z oblastí s najrozvinutejšou textilnou produkciou - továrnikov Ernesta Pfliegera z Bielitz (dnes Bielsko-Biala v Pol'sku) v Sliezsku (železné valchy, cylindrické postrihovacie, apretovacie a kartáčovacie stroje), Richarda Hartmanna v Chemnitz v Sasku (mechanické valchy, postrihovací stroj s dlhými nožmi, spriadacie stroje), obchodníka s rôznymi strojmi a zariadeniami A. Heydericha z Brna (dodal spriadacie a postrihovacie stroje a stoly, lisy, súčasti válch). ${ }^{38}$ Daniel Specker z Maschinenfabrik Am Tabor vo Viedni ${ }^{39}$ dodával a aj sám osádzal všetky stroje poháňané vodnou aj parnou energiou. Rokovalo sa s ním už v priebehu marca 1845, lebo kvôli zabezpečeniu náhonu strojov bolo treba vybudovat' jednak prívodné kanály zo síce výdatného, ale inak neregulovaného potoka, jednak zásobný tajch, aby fabrika nebola bez dostatočnej zásoby vody. Výkon sa totiž plánoval na 16 konských síl, $\mathrm{k}$ dispozícii však mala byt' aj dostatočná rezerva pre jeho budúce zvýšenie (v regióne boli d’alšie vodné toky). ${ }^{40}$ Išlo o pomerne náročné riešenia, ktoré realizoval inžinier Payne z Viedne. ${ }^{41}$ Predpoklad o rýchlom rozšírení výkonu sa rýchlo ukázal ako opodstatnený a už po roku prevádzky sa muselo pristúpit' k úprave náhonov. Obchodno-odborné kontakty boli bezpochyby vecou riaditel'a fabriky Rudolfa Wilhelma Wrchovszkeho, potomka skalickej súkenníckej rodiny, ktorá sa v priebehu 19. storočí zaradi-

Jahre 1845 uvádzal k 31. 12. 1845 o. i. úhradu 779 zl. k. m. za 22 tkáčskych strojov (Webzeuge), za vybavenie farbiarne skalickému medikováčovi Karlovi Strakovi 4678 zl. 05 gr. k. m., Heyderichovi z Brna za kovania na počesávacie stroje (Kratzmaschinen) $2965 \mathrm{zl}$. 35 gr. k.m., za farbiarsky lis 278 zl. 51 gr. k. m. a 78 platní na lisovanie 255 zl. 36 gr. k. m., za železný lis na súkno fabrike v Blansku 551 zl. k. m., úhradu 61 zl. 45 gr. k. m. za 12 kief na apretúru, za rôzne laná Antonovi Kuklovi z Brna 272 zl. 53 gr. k. m., za štyri stroje á 1200 zl. k. m. na apretovanie súkna a d’alšie súčiastky Ernerstovi Pfliegerovi z Bielska 6975 zl. k. m., Hartmannovi z Chemnitz za spriadanie a valchovacie stroje 5918 zl. 45 gr. k. m., Speckerovi z Viedne am Tabor za stroje na vodný pohon 12500 zl. k. m. SNA, Fond Zay - Súkenka, Účty z prvého roku existencie súkenky (knihy, doklady) 1845, k. 582.

38 Fabrika však občas nakupovala aj jednoduchšie zariadenia, napr. od trnavského Jozefa Sčipeka odobrala dva tkáčske stavy v cene $20 \mathrm{zl}$. k. m.

39 Stručnú charakteristiku jeho továrne na rôzne stroje pozri in Bericht über die dritte allgemeine österreichische Gewerbe-Ausstellung in Wien. Wien: Hof- und Staatsdruck, 1845, zv. 3, s. 866-867. Dostupné online [cit. 2017-02- 23]: https://books.google.sk/books?id=I5FlAAAAcAAJ\&dq=Daniel+Specker+Am+Tabor+Wien\&hl=sk\&source=gbs_navlinks_s

40 SNA, Zay - Súkenka, Korešpondencia, k. 592, s. 1, 2-3 (listy D. Speckerovi z 15. a 28. 3. 1845). Hladina tajchu mala mat' prevýšenie jednu siahu (cca $150 \mathrm{~cm})$, aby sa dosiahla potrebná sila náhonu.

41 Išlo zrejme o inžiniera Henryho Paynea, pôvodom zo Stockportu v Anglicku, ktorý sa pred 1845 zdržiaval v Sasku. Payne sa zaoberal vývojom jednoduchých spriadacích strojov a mal vo Viedni svojho splnomocnenca. Na stavbu takéhoto stroja získal 25. 3. 1844 aj patent (privilégium). Pozri Sammlung der Gesetze für das Erzherzogthum Oesterreich unter der Ens, zv. 26/1844. Wien 1846, s. 83. Dostupné online [cit. 2017-02-21]: https://play.google.com/books/ reader?id=ephXAAAAcAAJ\&printsec=frontcover\&output=reader\&hl=en\&pg=GBS.PP6 
la $\mathrm{k}$ pomerne významným podnikatel'om a z rodinnej manufaktúry dodala do Uhrovca niektoré menšie stroje. ${ }^{42}$ So Skalicou však fabriku spájali aj d'alšie nitky - väčšie množstvo vlny bolo treba dat' spriadat' aj externým partnerom, ktorými boli v tomto prípade podniky Pavla Mittaga a Ladislava Mazura. Ostatne, vlnu v okolí občas nakupoval d'alší Skaličan, Jacob Ehrenstein, inak nový nájomca Zayovskej (Gvadányiho) kúrie.

Stroje boli pochopitel'ne síce hlavným, no bezpochyby nie jediným predpokladom úspešnej výroby. Kým sa rozbehli, fabrika si musela zabezpečit' aspoň akú-takú známost', aby dokázala pokryt' nevyhnutne zložité obdobie rozbehu výroby. Reklama bola už pravidelnou súčast'ou dobovej tlače a ani Zay ako skúsený korešpondent viacerých novín tento aspekt nezanedbal. Okrem domácej tlače (Pressburger Zeitung) sa tak o otvorení fabriky od augusta 1845 mohli dočítat' aj vo viacerých zahraničných novinách. ${ }^{43}$ Fabrika začala svoju existenciu slávnostným „položením základného kameňa“ 8 . júla 1845 . Hoci pramene hovoria presne touto rečou, malo íst' skôr o otvorenie prevádzky, ved' reálne sa so stavbou začalo už v priebehu apríla 1845. Ako sa však ukázalo, napokon sa výroba nespustila ani $\mathrm{v}$ avizovanom augustovom termíne a až 8 . novembra 1845 mohol riaditel' hlásit' ukončenie stavby prevádzkovej budovy. Začala sa montáž už dodaných strojov a pomaly sa začínalo s výrobou - objednávok bolo totiž dost' už od zverejnenia otvorenia súkenky. Ešte aj v máji 1846 sa však dokončovalo l’avé krídlo fabrického komplexu. Napokon ho tvorilo viacero poschodových budov, v ktorých boli umiestnené prevádzky, sklady s fabrickým obchodom a pravdepodobne aj služobné byty a ubytovňa pre robotníkov z lokalít mimo Uhrovca. Zay pri projektovaní pravdepodobne využil služby stavitel'a Feiglera, ${ }^{44}$ aj ked' nie je isté, ktorého z vtedy už paralelne pôsobiacich architektov. ${ }^{45}$

Hoci stavba meškala, zodpovedala modernému štandardu vtedajšieho stavebníctva. Strechu pokrýval pozinkovaný plech, vykurovanie bolo zrejme zabezpečené prostredníctvom ústredného kúrenia. Nasvedčuje tomu dodávka dvoch kusov vel'kých liatinových kachiel' s vonkajším prikladaním (teda mimo vykurovanej miestnosti) v cene $1800 \mathrm{zl}$. k. m. za kus, spolu s vodovodnými rúrami

42 Roku 1846 išlo napr. o 5 ks Webstühle zu Hosenstoffe, 5 ks Webgeschirre, 1 Jaquart Maschine z dielne Ernesta Wrchovszkeho. SNA, fond Zay - Súkenka, Účtovné knihy, Cassa-Buch 1846-1850, k. 578: Prima-nota Buch der Zay-Ugroczer Tuch Fabrik für das Jahr 1846.

43 Uvádzajú Vereinigte Frauendorfen Blätter, č. 4, 24. 1. 1846. Dostupné online [cit. 2017-10-07]: https://books.google.sk/books?id=1BlAAAAAcAAJ\&printsec=frontcover\&hl=sk\&source $=$ gbs_ge_summary_r $\&$ cad $=0 \# \mathrm{v}=$ onepage $\& \mathrm{q} \& \mathrm{f}=\mathrm{fal}$

44 Vo februári 1846 bola uhradená položka Mauermeister Feigler 11 zl. 60 gr. k. m. za vykonanú revíziu (Schätzung).

45 Pôsobenie Feiglerovcov podrobnejšie analyzuje POHANIČOVÁ, Jana - BUDAY, Peter. Storočie Feiglerovcov. Pribeh bratislavských architektov, stavitel'ov a stavebných podnikatel'ov. Bratislava: Trio publishing, 2016. ISBN 9788097154042. 
a Heiz- oder Feuerungsröste - pravdepodobne nejakého typu radiátorov. Súčast'ou stavby bolo aj dotvorenie vonkajšieho vzhl'adu - pred farbiarňou do uličnej strany stál liatinový plot, od marca 1846 bol komplex obohnaný aj živým plotom z 3071 kusov hlohu.

Pre Uhrovec bola slávnost' kladenia základného kameňa nepochybne výnimočnou udalost'ou, presahujúcou formy obvyklých festivít. ${ }^{46}$ Plán na jej konanie mal Zay už v apríli 1845, ked' so županom Trenčianskej stolice Marczibányim dohodol otváraciu reč. Program zostavil v tom čase ešte fiškál grófa Karola Zayho Frantz (Ferenc) Makláry-Pappsász, podslúžny Trenčianskej stolice a člen Uhorského hospodárskeho spolku (Magyar Gazdasági Egyesület): začal sa ranným príchodom hostí z Bánoviec (slúžni Alexander Látkóczy, Juraj Ottlik a i.) v sprievode kočov členov rodiny, Karoly Zayho a župana Trenčianskej stolice. Uvítací ceremoniál pred budovou kaštiel'a otvorila hudobná produkcia troch bánovských trubačov na koňoch, 25 gajdošov a príhovory katolíckeho a evanjelického farára $\mathrm{v}$ mad'arčine a majstra zhromaždeného tkáčskeho cechu v slovenčine (szlav nyelvben). Nasledovalo vystúpenie 19-členného spevokolu zloženého zo služobníctva a domácich obyvatel'ov. Hostia sa potom odobrali do kaštiel'a, pričom schodište zdobili citrónovníky a pomarančovníky a dievčatá s kvetmi. Nasledovalo odovzdanie pamätných zlatých a strieborných mincí zobrazujúcich základný kameň s pergamenom, na ktorom boli vyryté mená hostí (pravdepodobne adresne pre každého obdarovaného). Po odpočinku sa sprievod odobral $\mathrm{v}$ sprievode hudby $\mathrm{k}$ fabrike, v ktorej boli už nainštalované niektoré stroje (stavy), zatial' však nekompletné - chýbali im špulky... Aj tu odzneli pozdravné reči - podlužanský evanjelický farár predniesol krátky príhovor po mad’arsky, uhrovecký po slovensky, nakoniec katolícky farár z Uhrovca po latinsky. Akt položenia základného kameňa uskutočnil murársky majster oblečený v červenom odeve: uložil do zeme kameň a k nemu puzdro so sklenenou nádobou s pamätným pergamenom a pamätnými mincami. Nasledoval príhovor župana a pod'akovanie Zayho. Po hodinovej prestávke sa podával v sieni koniarne slávnostný obed, počas ktorého znela hudba trenčiansko-teplických kúpel'ných muzikantov aj prípitky na grófa, jeho manželku, palatína, panovnícku rodinu, dom, župana, Trenčiansku stolicu a jej vojsko, viacerých uhorských šlachticov a všetkých hostí. Po hostine sa sedelo (a asi aj hralo) pri kartových stolíkoch, aby sa celé podujatie napokon zakončilo vel'kou večerou a punčom, opät' za zvukov hudby.

Honosná slávnost' nebola lacnou záležitost’ou: náklady na ňu dosiahli vyše 1365 zl. k. m. Najväčšiu položku tvorili náklady na ubytovanie pozvaných (vrátane služobníkov, kočišov, účinkujúcich a až 170 nádenníkov) v Bánovciach

46 K fenoménu slávenia pozri KUŠNIRÁKOVÁ, Ingrid a kol. „, Vyjdeme v noci vo faklovom sprievode a rozsvietime svet “. Integračný a mobilizačný význam slávnostív živote spoločnosti. Bratislava: HÚ SAV, 2012. ISBN 9788089396207. 
a Uhrovci, honorár pre trubačov a hudobníkov, a pochopitel'ne, výdavky na hostinu a podávané víno (vyše 178 zl.). Makláry objednal 50 fliaš šampanského, 64 fliaš vína Neustadler (vtedy oblúbený druh červeného vína) z viníc grófa Jozefa Erdödyho ${ }^{47}$ a sud obyčajného vína, platila sa však aj konzumácia hostí počas ich zastávky v kúpel'och v Trenčianskych Tepliciach. Slávnosti dodávali lesk aj početné zástavy mal'ované maliarom Deutschom, ozdobné náradie asistujúcich remeselníkov (tí dostali aj nové košele), vel'ký mal'ovaný a zlátený nápis na vstupe do fabriky, naleštené šable $\mathrm{z}$ hradnej zbrojnice, striel'anie $\mathrm{z}$ mažiarov a po šest' večerov (od 30. júna) vatra na vrchu Garazne. Vo vyúčtovaní sa však objavili aj kuriózne položky - bolo treba uhradit’ škodu za poničené pole miestneho poddaného, ktorá vznikla pri vození dreva a kameňa na Garazne, ale aj za vybuchnutý mažiar, ktorý bol požičaný od grófa Nyáryho.

\section{Personálne a prevádzkové otázky}

Významnou výhodou, hovoriacou $\mathrm{v}$ prospech Uhrovca ako sídla továrne, sa zdalo byt' miestne obyvatel'stvo, ktorého kultúrnu úroveň panstvo dlhodobo kultivovalo. V mestečku pôsobila škola s pomerne dobrou úrovňou, odkial' pravidelne odchádzali žiaci na gymnaziálne štúdiá: len v Prešporku v prvých decéniách 19. storočia študovalo sedem chlapcov priamo z Uhrovca, pravdepodobne s prispením panstva. Počas pôsobenia Samuela Štúra v Uhrovci Imrich a Mimi Zayovci zabezpečili aj chod mimoriadnej triedy, kde sa vyučovala špeciálne nemčina. Trieda mala zvláštneho učitel'a (podl'a všetkého úradníka panstva) a skúšky jej žiakov (chlapcov aj dievčat) navštevovali aj obaja fundátori. V kaštieli mal Imrich, inak riadny majster kníhviazačstva, vlastnú dielňu, v ktorej spolupracoval práve so Samuelom Štúrom. Náboženskými knihami, ktoré zviazal sám alebo v spolupráci so Štúrom, obdarovával počas života aj na základe testamentu viacerých uhroveckých obyvatel'ov, čo predpokladá čítanie kníh v domácnostiach poddaných. Medzi nimi bolo pomerne rozšírené domáce tkanie (tkáči mali v Uhrovci vlastný cech) a z nich sa neskôr grupovala aj čast' zamestnancov fabriky.

Vel'kost' továrne, resp. objem vyrábaného tovaru a rozmanité pracovné úkony, medzi ktoré patrila aj obsluha a údržba komplikovaných strojov, zapríčinili, že osadenstvo fabriky sa nemohlo viazat' len na obmedzený pracovný trh $\mathrm{v}$ Uhrovci, resp. $\mathrm{v}$ rámci panstva. Vedenie fabriky muselo zabezpečit' podmienky pre prácu a ubytovanie najatých robotníkov a robotníčok aj zo vzdialenejších lokalít. ${ }^{48}$ Napríklad v novembri - decembri 1847 bolo medzi 90 robotníkmi

47 Táto odroda sa inzerovala aj v Pressburger Zeitung 9. 6. 1837, s. 459.

48 Za postele a matrace pre postele v továrenskej ubytovni sa r. 1845 vydalo 105 zl. 20 gr. Dodávku realizoval stolársky majster Donay z Topol'čian. Podl'a Auszug der Fabriks Einrichtung Ausgaben für Jahr 1845. SNA, Zay - Súkenka, Účtovné knihy, k. 591, č. 2. 
16 tkáčov pôvodom priamo z Uhrovca, ale až 13 pochádzali z lokalít v zahraničí (okrem Moravy a Čiech aj z Pruska, Bavorska, Pol'ska); ostatní sa grupovali z bližšieho či vzdialenejšieho okolia. Vybudovanie a zariadenie ubytovne bolo preto jednou z hlavných úloh. Majstrom špecialistom sa poskytovali služobné byty ( $\mathrm{v}$ čase zariad'ovania fabriky bývali dokonca $\mathrm{v}$ kaštieli) vrátane nákladov na svetlo a kúrenie, $\mathrm{k}$ tomu aj úhrada nákladov na st’ahovanie. V prípade, že služobný byt nebol vol'ný, dostávali finančnú náhradu; ani vel'korysé platové podmienky však nedokázali prilákat' potrebný odborný personál. Preto sa pri objednávkach nových strojov prihliadalo aj na ich zložitost', resp. jednoduchost' následnej údržby: preferovali sa také, pri ktorých sa v prípade poruchy nepredpokladala nutnost' privolávat' opravárov z dodávatel'ských fabrík. ${ }^{49}$

Nielen komplikované stroje boli zdrojom problémov. Technológia si vyžadovala skúseného farbiara, od ktorého zručnosti závisela kvalita farebného prevedenia látok. Práve obsadzovanie tohto postu nebolo jednoduché a vedenie fabriky muselo zvyšovat' ponuku benefitov pre vytipovaných kandidátov. Prvému oslovenému Ernestovi Kupferovi z Lindow pri Neu Ruppin (kraj Potsdam) v Prusku slúbili v apríli 1845 plat 400 zlatých konvenčnej meny, no o dva mesiace neskôr už d'alšiemu kandidátovi Hermannovi Müllerovi z Brna ponúkali ročne $500 \mathrm{zl}$. k. m. Až táto suma zodpovedala podmienkam na trhu, čo však Karol Zay bral podl'a všetkého s nevôl'ou. Müller si vypýtal čast' platu vopred, hoci nábor ostatných zamestnancov sa v čase jeho nástupu (1. septembra 1845) ešte len začínal - stroje totiž stále neboli na mieste. Ani slušné platové podmienky ale nemohli zabezpečit' stabilitu a kvalitu pracovníkov, a práve farbiarski majstri mali vzhl'adom na svoju profesiu ,navrch“. Müller bol už koncom mája 1846 na dovolenke doma $v$ Brne a zrejme sa odmietol vrátit', lebo už o mesiac sa riaditel'stvo dohadovalo na nástupe s novým adeptom, aby sa potom v septembri 1847 aj na jar 1851 situácia opakovala. Vedenie malo dokonca podozrenie, že Uhrovec sa stal ciel'om l'udí, ktorí bažili po rýchlom a l'ahkom zbohatnutí. ${ }^{50}$ Pri hl'adaní nových pracovníkov sa preto nespoliehalo len na uchádzačov, čo sa hlásili na vypísané inzeráty, ale obracalo sa na svojich obchodných partnerov (najmä na Morave) alebo aj bývalých zamestnancov (H. Müller) so žiadost’ami o sprostredkovanie. ${ }^{51}$ Zvýšilo aj ponuku na odmeňovanie a vybraný uchádzač sa z nástupného platu $500 \mathrm{zl}$. k. m. ročne mohol v priebehu dvoch rokov dostat' až na 700 zl. k. m. ročne pri zachovaní iných pôžitkov. ${ }^{52}$

49 17. 9. 1850, list adresovaný dodávatel'skej továrni v Chemnitz. SNA, Zay - Súkenka, Korešpondencia, k. 592, s. 328.

50 List riaditel'a z 27. 10. 1846 adresovaný A. Heyderichovi do Brna. Tamtiež, s. 71-72.

51 Podobné problémy, ale s majstrom valchárom riešilo vedenie fabriky s Richardom Hartmannom z Chemnitz 27. 1. 1848. Tamtiež, s. 157.

52 Podl'a listu z 11. 4. 1851, adresovaného H. Müllerovi do Brna. Tamtiež, s. 361-362. Do úvahy 
Osadenstvo fabriky sa pochopitel'ne skladalo z viacerých kategórií zamestnancov. $\mathrm{V}$ dobe stavby budovy sa o organizovanie prác staralo priamo Karolom Zaym dezignované vedenie fabriky, ktoré sa utvorilo z jeho osvedčeného hospodárskeho personálu na čele s fiškálom Maklárym. Vedenia fabriky sa po ňom ujal R. W. Wrchovszky, ktorý sa zdržiaval zväčša vo svojej kancelárii vo Viedni, odkial' až do 31. októbra 1851 riadil zahraničné kontakty, dovoz a distribúciu tovarov, ${ }^{53}$ účtovník Carl Szokolóczy ${ }^{54}$ a kancelista pisár Ludwig Gregusch. ${ }^{55}$ V rebríčku zamestnancov nasledovali majstri jednotlivých zložiek výroby. Okrem už spomínaného majstra farbiara to boli majster spriadania (Spinnmeister) Bruno Walter, resp. R. Kanth, majster valchár (Walkermeister) Fridrich Schipelt, majster apretovania (Apreturmeister) Carl Nikisch, od marca 1846 pribudol aj majster tkania (Webermeister) Wolf, neskôr F. Hillebrandt. K dobre plateným zamestnancom patrili aj lekárnik a lekár Burstein. Prvému sa uhrádzalo bývanie a skutočné náklady za vydané lieky, druhý dostával fixný plat 250 zl. k. m., pričom pochopitel'ne, obaja mali aj d’alšie príjmy od súkromných pacientov. Vo fáze montáže strojov sa na dlhšiu dobu najímali dodávatel'mi sprostredkovaní montéri a údržbári, neskôr sa s rozvojom výroby odborný personál doplnil o špecializovaného zámočníka strojníka (Schlossermeister) Dvoraka (ten mal aj pomocníka učňa), tesára (Fabrik Tischler) Grünnwalda a aj d’alšieho zamestnanca pokladne (Imrich Kollosek). Ich platy boli pochopitel'ne diferencované. Mesačná výplata zamestnancov odborníkov dosiahla napr. vo februári 1846 spolu 316 zl. 40 gr., ale postupne s rozbiehaním výroby rástla aj táto zložka výdavkov - v septembri to už bolo 1047 zl. a v decembri 1431 zl. k. m.

Budovanie a chod fabriky si pochopitel'ne vyžadovali aj d'alšie špecializované profesie. Stavebný materiál - tehly zabezpečoval majster tehliarskej výrobne Vaik, dozor nad pracovníkmi (evidencia dochádzky) vykonávali dvaja úradníci, fabrika potrebovala aj troch stálych kočišov. Početní námedzní majstri (klampiari, stolári) boli najímaní priamo na panstve podl’a potreby a vyplácaní v týždenných intervaloch. Niektorí z nich boli angažovaní pri zvláštnych prácach aj neskôr. Napríklad rómsky („,cigánsky“) kováč Jonann Rácz z Uhrovca bol platený za pravidelné dodávky špeciálnych klincov do rámov na sušenie súkna.

treba síce vziat’ pohyb hodnoty meny, ale rast výšky platov, spôsobený nedostatkom kvalitných pracovníkov, trápil vedenie fabriky aj v iných prípadoch.

53 DÚBRAVSKÝ, Ferdinand. Uhorská Skalica, uvádza R. Vrchovského (20. 2. 1816 - 17. 3. 1901), pôvodom zo Skalice, ako majitel’a špedičnej firmy vo Viedni. Skalický zayovský majetok a spoločné vierovyznanie boli zrejme dôležitými styčnými bodmi pri angažovaní potomka významnej súkenníckej rodiny zo Skalice. Pozri Zlatý fond denníka SME 2013, dostupné online [cit. 2017-10-06]: http://zlatyfond.sme.sk/dielo/1824/Dubravsky_Uhorska-Skalica/11

54 Carl Szokolóczy mal spočiatku na starosti nielen riadenie bežnej prevádzky fabriky, ale aj celého zayovského majetku, preto od r. 1849 účtovníctvo fabriky prebral Michael Brand.

Pravdepodobne išlo o syna bučianskeho záhradníka. 
Jednorazovými prácami pri viazaní rôznych kníh (viazané výkazy, knihy nariadení) si vypomáhal dokonca aj Samuel Štúr.

Najväčšia t’archa výroby a zároveň úspech podniku spočívali pochopitel’ne na priamych producentoch - spriadačoch, tkáčoch, farbiaroch, postrihovačoch a iných kategóriách fabrických robotníkov. Ich počet sa $\mathrm{v}$ sekundárnej literatúre skôr odhadoval, výkazy fabrického nemocenského fondu však umožňujú rekonštrukciu presného počtu pre každý týždeň pracovného roka. V priemere sa v prvom roku činnosti venovalo rôznym úkonom vo výrobnom procese $75-90$ robotníkov/-čok. V revolučnom roku 1848 (v zaznamenanom období od 7. 2. do 30. 12. 1848) ich bolo v rozpätí 71 - 90/týždeň, po upokojení pomerov (7. 2. 31. 3. 1849) sa počet robotníkov pohyboval bežne medzi 113 - 149. Treba však uviest' aj anomálie - týždne, počas ktorých počet robotníkov vykázal extrémny pokles, či naopak, nárast: od 19. júna do 10. júla bolo v pracovnom pomere 54 a 57 zamestnancov, počas prostredného týždňa dokonca pracovala len spriadačská dielňa s 12 pracovníkmi. Hypoteticky možno tento pokles pripísat' (ak neberieme do úvahy možnost' nedokonalej evidencie) nejasnostiam okolo zavedenia novej uhorskej meny a zrejme s tým spojenému obmedzeniu produkcie. Podobná situácia nastala aj počas prvých dvoch týždňov októbra, ked' sa počet robotníkov/-čok znížil z obvyklých cca 77 až 80 počas jesene na 49 a 52 . To už bol vyhlásený a čoskoro aj suspendovaný výnimočný stav a cisárske vojsko dostalo príkaz na potlačenie revolúcie v Uhorsku. Od začiatku novembra sa situácia vo fabrike ustálila na angažovaní cca 80 robotníkov. Extrémny nárast priniesol týždeň od 20. januára 1849, ked' sa pri strojoch striedalo až 219 robotníkov. To už bola fabrika približne od jesene 1848 angažovaná pri produkcii súkna na uniformy pre stoličné vojská a prvých objednávkach od Monturs Commission. Vinou zmätených pomerov však viazol odbyt a úhrada platieb. ${ }^{56}$

Uhrovecká fabrika bola priekopníčkou aj v oblasti zamestnávania žien. ${ }^{57}$ Textilný priemysel sa rýchlo stal ich doménou. Menej časté však bolo, aby sa už v tomto období ženy dostávali aj na miesto majsteriek - alebo jednoducho nie je dost' dokladov o organizácii práce v prvých manufaktúrach a fabrikách. V prípade Uhrovca však vieme, že ženy robotníčky tvorili až polovicu osadenstva prispievajúceho do nemocenského fondu. ${ }^{58}$ Za prácou chodili aj zo vzdialenejších lokalít a do značnej miery boli odkázané na fabrickú ubytovňu. Ich prácu riadili majsterky, ktoré vedenie vybralo na základe „konkurzu“. Posúdenie ich kvalít však bolo zrejme spočiatku istým problémom. V lete 1846 sa riaditel'stvo

56 Pozri SNA, Zay - Súkenka, Korešpondencia, k. 592, list z 23. 1. 1849.

57 Teraz nechám bokom otázku robotární, kde išlo síce o prácu žien, ale formou prinútenia, a nie využitia obchodno-pracovného vzt’ahu. K fenoménu robotární pozri ŠPIESZ, ref. 4, s. $228-238$.

58 Napríklad počas prvej polovici roka 1849 pracovalo v továrni 35 robotníkov a 58 robotníčok. 
informovalo u svojho spol'ahlivého partnera Heinricha Heydericha z Brna, či vie sprostredkovat' ním overenú nemenovanú uchádzačku, lebo na vol'né miesto majsterky sa hlásilo sedem záujemkýň! Nečudo, ked’že platové podmienky neboli zlé: týždenný plat $3 \mathrm{zl}$. k. m. predstavoval vyše $150 \mathrm{zl}$. k. m. ročne a k tomu obvykle aj bezplatné bývanie a kurivo. Na druhej strane však práve robotníčky boli nestálou pracovnou silou a v obchodnej korešpondencii sa niekol'kokrát v sledovanom období vyskytujú st’ažnosti na nedostatok tkáčok nopkovačiek (Nopperinnen).

Po nábehu výroby a rozvinutí obchodovania pribudla d’alšia významná kategória pracovníkov: za priamo fabrických zamestnancov možno počítat' vedúceho skladov zásob a vyrobeného tovaru (Magaziner), de facto vedúceho obchodu v Uhrovci Johanna Schnittara (po ňom sa uvádza Jozef Molitorisz) a s istou benevolenciou aj vedúcich obchodných zastúpení v Pešti (F. Makláry) a Prešporku (Johann Kodrits/Köttrich). Práve im od roku 1846 pripadla hlavná úloha pri hl'adaní obchodných partnerov, distribúcii tovaru, vyjednávaní objednávok a reprezentácie fabriky v mieste pôsobenia. V obidvoch obchodoch sa Karol Zay často osobne vyskytoval. Makláry patril navyše do kruhu jeho blízkych priatel'ov. ${ }^{59}$ Práve od jeho schopnosti nadväzovat' kontakty s centrálnymi úradmi záviselo získavanie a vybavovanie vel'kých objednávok. Zakrátko si súkenka otvorila aj d'alšie predajne, kde sa sústred'ovali objednávky z rôznych regiónov. Fabriku tak reprezentovali aj obchody v Trnave (Eduard Richter) a Trenčíne (Jozef Tejfelesi), roku 1847 nakrátko v Deutsch Altenburgu a Györi a hlásili sa aj d’alší. ${ }^{60}$ Búrlivý rok 1848 však zredukoval počet predajní na štyri - v Uhrovci, Prešporku, Nitre (Ladislaus Trsztyenszky) a Pešti, hoci aj v tejto dobe sa o možnost' zastupovat' fabriku hlásili noví záujemcovia (M. S. Boschán z Miskolca).

V skutočnosti aj pri týchto „firemných“ obchodoch išlo o formu komisionálneho predaja, ked’ vedúci (stále majitel') obchodu pristúpil na „normovanú“ dohodu ohl'adne prevádzky. Náklady na zariadenie obchodu a obchodné cesty išli na účet obchodníka, pretože ten zostal majitel'om obchodného priestoru. Zay však chcel mat' vonkajší vzhl'ad obchodov v jednotnom dizajne a trval na tom, že majitel' predajne vyvesí štít alebo nástennú tabul'u, ktorej vyhotovenie (bezpochyby v rovnakom štýle) zaplatí fabrika. ${ }^{61}$ Tovar sa posielal predajcovi na faktúru (Franco), bol však vo vlastníctve fabriky, až dokial' nebol zaplatený. Obchodník mal mesačne posielat' získané tržby, ale ako sa ukázalo, kvôli meškajúcim platbám sa viedla častá a ostrá korešpondencia. Fabrika si dala aj podmienku,

59 Zayho pravidelné návštevy v obchode v Prešporku dokladajú početné zápisy v jeho denníku z príslušných rokov. SNA, fond Zay - Karol Zay, Mária Kollowrat (denník), k. 220.

60 Dňa 15. 2. 1846 sa o otvorenie firemného odchodu usiloval Franz Gerometta zo Žiliny, ale bol odmietnutý, podobne ako F. L. A. Burian z Kremnice, 14. 2. 1848 Andreas Skultety zo Žiliny.

61 Ako maliari sa uvádzajú bližšie nemenovaní Winkler a Deutsch. 
že v obchode sa nebude predávat' žiaden cudzí tovar, podobný jej produktom. Zato však poskytovala províziu $2 \frac{1}{2}$ grajciaru za cent tovaru, čo sa však čoskoro zmenilo na bežnejšiu účtovnú formu piatich percent rabatu. Obchodníci sa predháňali v snahách získat' status fabrického obchodu, lebo si bezpochyby sl'ubovali bezproblémovú dodávku tovaru a ani prípadné vrátenie nepredaného tovaru nemal byt' problém. „Kamenné obchody“ už boli trvalejšou, a preto výhodnejšou formou nákupu a predaja tovaru, ako stáročia praktikované vystavovanie tovaru na trhoch a jarmokoch. Ani tie však nevypadávali z obchodných aktivít a pravidelne sa robili zásoby k termínom ich konania. Najviac bol cenený svätojánsky trh v Pešti, kde sa schádzali obchodníci z celého Uhorska. Vel’mi rýchlo pribudla aj d'alšia možnost' prezentácie na priemyselných výstavách, tie sa však konali častejšie až v období mimo záujmu tejto štúdie.

Vo viacerých prípadoch obchodníci neodhadli množstvo objednaného tovaru a látky nedokázali predat'. Fabrike tak nesplácali faktúry načas a dodávatel'sko-odberatel'ské vzt'ahy sa začali kazit'. Nasledovali upomienky na vyrovnanie pohl'adávok a niekedy aj vyhrážky súdnym procesom. Platobná disciplína sa uvol'nila najmä na jar 1848, ked' nejasné pomery a rozvrat bezpečnosti v Uhorsku st’ažili obchodovanie. ${ }^{62}$ Tieto upomienky mali úspech a je zaujímavé, že vedenie súkenky po vyrovnaní dlhov d'alej spolupracovalo $s$ bývalými veritel'mi. Zrejme malo pochopenie pre t’ažkosti v podnikaní, lebo samo sa dostávalo do situácie, ked' hrozilo nezaplatenie za tovar, ktorý sa objednalo (farbivá, súčiastky). Urgencie dlhov boli preto sprevádzané aj odkazmi na to, že fabrika nesmie upadnút' do dlhov, či aspoň nesmie mat' dlhodobo nezaplatené účty a riskovat' svoje dobré meno. V tomto odkaze možno vnímat' étos aristokratického majitel'a s tradičným vnímaním konceptu (šl'achtickej) cti, ale aj doby, ked'sa podnikanie ešte odohrávalo viac-menej na osobnej úrovni a ,povest““ bola dôležitou obchodnou výhodou.

Vedenie fabriky sa však stretávalo aj s nedbanlivým vybavovaním svojich požiadaviek. Takúto skúsenost' mali napr. s dodávatel'om strojov na apretovanie Ernestom Pfliegerom z Bielitz, ktorý stroje určené pre Uhrovec odoslal celkom inému zákazníkovi a dodal ich až po upomienke; takéto konanie ho stálo odpočítanie nákladov na prepravu. Pikantné však je, že neoprávneným adresátom bol d’alší z obchodných partnerov súkenky Hartmann z Chemnitz, ktorý mal súkenke dodat' podobné stroje. Riaditel'stvo sa o tom dozvedelo, ale od kontraktu ani s jedným neodstúpilo - aj preto, že predpokladalo potrebu skorého rozšírenia výroby a využitia oboch dodávok.

62 Pozri listy Köttrichovi do Prešporku, L. A. Burianovi do Kremnice, Ladislausovi Trsztyanszkemu do Nitry, A. Skultetymu do Žiliny zo 17. 4. 1848. 


\section{Fabrika a rôzne typy objednávok}

Zabezpečit' rentabilitu podnikania $\mathrm{v}$ textilnom priemysle, kde panovala vysoká konkurencia, nebolo jednoduché. V prospech produktov sa už bežne využívala reklama. V prípade súkenky v novinách Pesti Hirlap, Magyar Gazda, Jelenkor, Buda-Pesti Hiradó, Hetilap, Pester Zeitung a Pressburger Zeitung, ale informácie o nej sa objavili aj v zahraničných novinách. Fabrika mala pripravené vzorkovníky látok, ktoré boli k dispozícii vo fabrických obchodoch a na ich základe sa kontrahovali odhadované množstvá. V ponuke boli súkna a látky rôznej kvality - mundúrové, livrejové, súkno na konské deky, nohavicové látky, módne sezónne látky (zimné/letné), všetky v rôznych farbách. Do výroby sa však zadávali aj vlastné návrhy od obchodníkov, avšak za podmienky, že na výrobu sa ponechá časová rezerva (cca do troch mesiacov). Drobní odberatelia boli dôležitým typom zákazníkov, ale problémy s platením faktúr vedenie presvedčili, aby hl'adali vel'koodberatel'ov - a takými sa stali všetky organizácie, ktoré potrebovali pre svojich príslušníkov jednotné oblečenie (uniformy). Patrili k nim rôzne panstvá, ktoré niektorým kategóriám svojich zamestnancov poskytovali livreje ${ }^{63}$ stolice, ktoré zaodievali svojich hajdúchov, ${ }^{64}$ armáda, resp. jednotlivé vojenské jednotky (pluky), riaditel'stvá komorských panstiev a po revolúcii aj stoličné vojsko, domobrana či žandárstvo. Práve revolúcia bola napriek komplikovaným pomerom $\mathrm{v}$ doprave a zabezpečovaní platobného styku motorom výroby v Uhrovci: stoličné oddiely (Hontianskej, Trenčianskej aj Nitrianskej stolice) mali aj vyše tisíc členov a potrebovali jednotné uniformy (často v národných farbách). Svoje objednávky smerovali práve do Uhrovca.

Uniformy poskytovali vysokú mieru stability produkcie, ktorú však na druhej strane sprevádzali nižšie stanovené nákupné ceny. O tom, že fabrika bola vyt'ažená výrobou pre potreby cisárskej armády, svedčia doklady o objednávkach zo strany uhorskej Monturs-Commission. ${ }^{65}$ Práve prvé objednávky z leta - jesene 1848 robili vedeniu fabriky starosti, lebo cena bola podl'a neho stanovená príliš nízko. ${ }^{66}$ Navyše, výrobu v tomto hektickom období skomplikovalo zrútenie

63 V sledovanom období išlo o Erdödyho panstvo v Továrnikoch, panstvo grófa Königsegga-Aulendorfa, levické panstvo kniežat’a Eszterházyho, panstvo grófa Hunyadyho. Na livreje sa vyžadovalo kvalitnejšie súkno (typu Tosking), často farebné.

64 1847, Hontianska, Liptovská stolica.

65 Komisie zriadené pre jednotlivé krajiny monarchie mali na starosti otázky dodávok uniforiem a zásobovania. Pozri MÜLLER, Franz. Die kaiserl. königl. österreichische Armee seit Errichtung der stehenden Kriegsheere bis auf die neueste Zeit: Nebst einer Beigabe: Notizen über die Bewaffneten Bürgen-Corps der größeren Städte der Monarchie. Band 2, Prag 1845, s. $228-230$.

66 List adresovaný obchodu v Pešti 4. 9. 1848. SNA, fond Zay - Súkenka, Korešpondencia, k. 592, s. 221-222. 
múru a následné poškodenie hnacieho kolesa valchy, ktoré zastavilo produkciu na tri týždne. Aby sa predišlo sankcionovaniu, komisii sa muselo predložit' potvrdenie zo súdu, že udalost' sa skutočne stala. ${ }^{67}$ Napriek problémom spolupráca s komisiou bola stabilizujúcim faktorom, lebo objem kontrahovaného súkna sa pohyboval v rastúcich tisíckach lakt’ov. Už prvá objednávka od Monturs-Commission predstavovala 6000 lakt’ov sivého a hnedého súkna, čo bol v januári 1849, dobe najväčších zmätkov v krajine, vítaný zdroj pre stabilizáciu výroby. Ďalšie objednávky už predstavovali ovel'a vyššie objemy. Napríklad objednávka z 3. a 5. 1. 1850, s termínom dodania do konca júla, určená pre jednotky novoorganizovanej žandarmérie, predstavovala 15000 lakt’ov modrého (á 36 grajciarov), 7500 lakt’ov hnedého (á 40 gr.) a 7500 lakt'ov ocel'ovo-zeleného (á 40 gr.) súkna. Do konca marca sa z tohto objemu malo expedovat' 6000 lakt'ov a potom každý mesiac do konca júla 1850 d’alších 6000 lakt’ov. ${ }^{68}$

Objem objednávok sa v d’alších rokoch zvyšoval, no finančný efekt nebol príliš potešujúci. ${ }^{69}$ Komisia sama určovala nákupné ceny a nebolo l'ahké dojednat' ich úpravu podl'a reálnej ceny vlny. Pri spomínanej objednávke sa to však podarilo a pri dvoch typoch súkna sa cena zvýšila (pri modrom súkne z 36 na 42 gr. á laket', pri zelenom zo 40 na 47), zato pri jednom znížila (pri hnedom zo 40 na 30), takže zisk bol napriek istému zvýšeniu cien viac-menej marginálny.

V porovnaní s komerčnými objednávkami je rozdiel $\mathrm{v}$ reálnych a komisiou určených cenách ešte výraznejší: práve roku 1850 objem komerčného tovaru dosiahol len 20 tisíc lakt’ov súkna, zato v hodnote 55 tisíc zlatých k. m.! Dodávky pre Monturs-Commission boli navyše problematické aj preto, že dôstojníci pri preberaní nachádzali také chyby, skutočné alebo domnelé, kvôli ktorým sa uplatňovali reklamácie a požiadavky na zníženie ceny. Uvádzal sa mierne odlišný farebný odtieň, nestálost' farieb, nerovnaká šírka, chybné tkanie atd'. Vedenie fabriky na výčitky reagovalo poznámkou, že ak by odstránili všetky chyby, dodané súkno by bolo kvalitnejšie než komisiou predložené (požadované) vzorky.

67 List adresovaný obchodu v Pešti 26. 9. 1848. Tamtiež, s. 226-227:

68 Platby mala realizovat' firma Pollak und Poppers Söhne.

69 Údaje podl'a SNA, fond Zay - Súkenka, Korešpondencia, k. 592.

\begin{tabular}{|l|r|r|r|r|}
\hline \multicolumn{5}{|c|}{ SUMÁR DODÁVOK SÚKNA V R. 1850 - 1859 } \\
\hline Rok & \multicolumn{1}{|c|}{ Monturs-Commission } & \multicolumn{1}{c|}{ Ostatné objednávky } \\
\hline & Množstvo & Cena v zl. & \multicolumn{1}{c|}{ Množstvo } & \multicolumn{1}{c|}{ Cena v zl. } \\
\hline 1850 & 30000 & 50000 & 20000 & 55000 \\
\hline 1853 & 35000 & 65000 & 22000 & 80000 \\
\hline 1859 & 56400 & 145000 & 8000 & 15000 \\
\hline
\end{tabular}


Problematická bola najmä požiadavka, aby sa fabrika zaviazala odmietnut' iné ponuky, a tak počas celej jari prichádzala o výhodné sezónne objednávky na „fajnovéc látky od stálych partnerov. ${ }^{70}$ Pritom to nebola jediná komplikácia súvisiaca s dodávkou pre armádu. Velenia niektorých uhorských plukov si neboli isté, či tovar majú preberat' priamo cez obchodné zastúpenie v Pešti, alebo sa im bude dodávat' prostredníctvom centrálnej Monturs-Commission. To by však znamenalo odoslat' baly látky do Viedne a zaplatit' clo, ktoré bolo stále uvalené na obchod medzi Rakúskom a Uhorskom. Uvedený spôsob dodávok by bol navyše úplne nelogický najmä v prípade objednávok pre 5. pluk žandarmérie dislokovaný v Košiciach. Tento obchod dohodol priamo Karol Zay s velitel'om pluku Ignazom von Talianom po ukončení ominózneho kontraktu s Monturs-Commission zo začiatku roka.

Reakcia obchodného vedenia fabriky na požiadavky komisie naznačuje, že nebolo príliš naklonené uvedeným zásahom majitel’a do obchodnej politiky. Blokovanie časti výrobných kapacít bolo komplikované nie príliš dobrými cenami aj problémami pri dodržiavaní kvality výroby. V liste adresovanom Ferencovi Maklárymu do Pešti sa riaditel' Wrchovszky jasne vyjadril, že ,,z celej transakcie so žandarmériou pozerá len strata a obchod sa nikdy nemal uzavriet’... "71 Ked' sa po výmene velitel'a objavili nedorozumenia ohl'adne spôsobu dodávky, celý kontrakt sa zastavil a narýchlo (aj na základe novinového inzerátu) sa hladal odbyt pre vyrobené súkno - tentokrát až u žandarmérie v Miláne, Viedni či Vel'kom Varadíne (Nagyvárad, Oradea, Rumunsko). Preto ked' Karol Zay v liste z 20. mája 1851 sa zmienil o možnosti novej objednávky zo strany žandarmérie, riaditel' fabriky sa domnieval, že by bolo účelnejšie, keby sa predbežne neprijala, nanajvýš na priame naliehanie, aj to s výhovorkou, že vyrábat' začnú, až ked' sa vybaví (naplní) bežiaci kontrakt. ${ }^{72}$

Jednoznačne formulované stanovisko a odporúčania riaditel'a, ako d'alej postupovat', svedčia o rodiacom sa spore medzi ním a majitel'om podniku. $\mathrm{Na}$ jednej strane aristokrat so zmyslom pre reprezentáciu, vernost' a službu panovníkovi a jeho orgánom, na druhej strane prevádzkový riaditel' zodpovedný za každodenný chod fabriky zápasiacej s nedostatkom pracovníkov, zadržiavanej hotovosti, stúpajúcimi nákladmi a niekedy až prehnanými požiadavkami zákazníka. Riaditel' preto navrhol niekol'ko principiálnych zásad, ak by sa rokovalo o novom kontrakte so žandarmériou. Malo sa o ňom hovorit' až po expedovaní poslednej dodávky, trvat' na podmienke obmedzeného množstva kontrahovaného tovaru (ročne nanajvýš 36000 lakt'ov v štvrt'ročných dodávkach) a na platbách v hotovosti. Špecifikácia kvality súkna mala byt' vecou generálnej in-

70 Za také sa označovali druhy Elastiques, Mousselins, Trapp croisie, Kornblau aj zimné látky.

71 List z 15. 1. 1851. SNA, fond Zay - Súkenka, Korešpondencia, k. 592, s. 344-345.

72 List adresovaný Karlovi Zaymu do Prešporku z 24. 5. 1851. Tamtiež, s. 369-370. 
špekcie, fabrika však chcela garantovat' len jednu (štandardnú) šírku balu látky a cenu prepočítavat' nie na dížku, ale plochu dodaného množstva. Stanovit' sa mala aj najnižšia akceptovatel'ná cena za laket', podl'a typu súkna v rozpätí 2 zl. 30 gr. -3 zl. 24 gr. k. m. Ked' onedlho v súvislosti s dodávkou pre Viedeň riaditel' písal o „nehoráznych (finančných) stratách“ (rozdiel v nákladoch a príjmoch za tovar bol 9832 zl. 25 gr. k. m.), spôsobených nutnost'ou nakupovat' „cudziu“ vlnu za zvýšené ceny (vlastná produkcia nepostačovala) a po pár mesiacoch, k 31. októbru 1851 sa vzdal miesta, je jasné, že spor nadobudol vel'kú intenzitu a pre podnik mohol mat' d'alekosiahle dôsledky. Wrchovszky sa po niekol'kých rokoch vrátil do rodného mesta ${ }^{73}$ a fabrika pokračovala vo svojom úsilí balansovat' medzi relatívne bezpečnými dodávkami pre štát a lukratívnou, no rizikovou výrobou móde podliehajúceho tovaru.

\section{„Colonien von Proletarier zu begründen habe ich keine Lust“: sociálne aspekty fungovania fabriky}

Fabrika celouhorského významu mala od svojho vzniku nesmierny význam pre formovanie sociálnych pomerov v Uhroveckej doline. Prácu získalo niekol'ko desiatok miestnych obyvatel'ov už pri stavbe a zariad'ovaní fabriky, v samotnej výrobe, ale aj neskôr pri expedícii tovaru. Počet robotníkov však pochopitel'ne kolísal podl'a objednávok a stavu fabrickej pokladnice. Kým sa nerozbehli dodávky pre stoličné oddiely, armádu a žandárstvo, výroba sa orientovala na rôzne vlnené látky, predstavujúce „,bežný“ a sezónny tovar - látky na obleky, nohavice, kabáty či livrejové súkna. Už roku 1846 sa objavil aj špecifický segment tovaru - trikolóry na klobúkové krempy, ktoré sa stali súčast’ou „národného“ odevu v predmarcovej dobe. Karol Zay už predtým zvažoval doplnit' produkciu o výrobu luxusného druhu tovaru, kvôli čomu sa v Uhrovci mala usadit' väčšia skupina čipkárov z Čiech. Zayho súputník Pavol Rázgha v snahách o reformovanie pomerov v evanjelickej a. v. cirkvi však odrádzal grófa od tohto kroku. Poznajúc pomery v Čechách, kde v tom čase pôsobil, predpovedal, že v konkurencii so strojovou výrobou neobstoja a $\mathrm{z}$, duševne aj telesne deformovaného l'udu “ sa stane škola proletárov a pauperizmu. ${ }^{74} \mathrm{~V}$ tomto fenoméne videl potenciálne nebezpečenstvo pre lokálne aj celouhorské sociálne pomery.

$\mathrm{V}$ uvedenom názore, ktorý si osvojil aj K. Zay, ${ }^{75}$ sa už ohlasovali obavy z prílišnej koncentrácie sociálnej skupiny, ktorej správanie bolo nepredvídatel'né a neriadilo sa dovtedajšími zaužívanými vzt’ahmi budovanými na osobnej závis-

73 Pozri pozn. 53.

74 Denník K. Zayho z 12. 4. 1845. SNA, fond Zay - Karol Zay, Mária Kollowrat (denník), k. 220.

75 V podnadpise uvedené slová použil K. Zay v zázname denníka z 2. 2. 1846, ako reakciu na ponuku usadit' 20 - 40 rol'níckych rodín v Uhrovci. Tamtiež. 
losti a paternalizme. Zay, sčítaný v dobovej ekonomickej literatúre a oboznámený s dianím vo vyspelejších krajinách, sa obával vypuknutia sociálne motivovaných nepokojov a ako jeden z prvých $\mathrm{v}$ rámci dobovej spoločnosti upozorňoval na hrozbu komunizmu. $V$ počiatočnej fáze existencie fabriky sa však vedenie nemuselo vysporadúvat' s prejavmi sociálneho napätia, skôr muselo čelit' nerovnomernosti pri zabezpečovaní dostatočného počtu pracovníkov, kvality ich práce a následkom pre proces výroby. Nejedno vysvetlenie meškania kontrahovaných dodávok operovalo s nedostatkom skúsených robotníkov a robotníčok. Dosvedčuje to aj porovnanie sumára vyplatených miezd v počiatkoch existencie fabriky a v období plnenia rozsiahlych dodávok pre armádu. Roku 1846 mzdy robotníkov a ostatného personálu fabriky dosiahli úhrn 31336 zl. 16 gr. k. m., no r. 1850 to bolo menej, len 27899 zl. 46 gr. k. m. Neustále meškanie dohodnutých dodávok ohrozovalo príjmy, kredibilitu fabriky aj existenciu jednoduchých robotníkov. Situáciu nepomohlo vyriešit' ani zachovanie reliktu dovtedajšieho modelu prípravy pracovníkov v rámci cechového systému - vo fabrike boli angažovaní aj učni a tovariši.

Prirodzenou reakciou na stúpajúce pracovné zat’aženie v súvislosti s dodávkami pre armádu boli požiadavky na zvýšenie platov, čo bola pre vedenie fabriky neočakávaná situácia. Stav latentného napätia bol viac-menej trvalý a zrejme by bolo otázkou času, kedy by sa objavili prvé náznaky sociálnych nepokojov. Napriek tomu k ničomu takému neprišlo. Práca v modernej fabrike predsa len poskytovala vyšší štandard príjmov a prít'ažlivou mohla byt' aj istá forma sociálneho zabezpečenia. Išlo o nepochybnú vymoženost' v prospech zamestnancov - nemocenskú pokladnicu, ktorá zo stanovených príspevkov kryla náklady na ošetrovanie počas choroby. Jej fond vznikol ako aplikácia modelu poistenia a prispievat' do neho bolo povinnost'ou všetkých zamestnancov bez rozdielu pracovného zaradenia - týkala sa teda aj členov riaditel'stva.

Nemocenský fond fungoval na základe obsiahleho štatútu z 1. novembra 1847, ktorý modernou formou artikuloval záujem zamestnávatel’a o optimálny stav svojich pracovníkov. ${ }^{76}$ Deklarovaný záujem nebol manierou alebo gestom navonok, ale zrejme vyjadroval vnútorné presvedčenie grófa Zayho o potrebe takejto základiny. Sám vložil do pokladnice fondu najvyšší vklad - 125 zl. k. m. Jeho príklad nasledovali aj d'alší členovia vedenia továrne (úradníci, majstri), aj ked' ich sumy sa pohybovali v rozpätí $10-25 \mathrm{zl}$. k. m. Fond sa však pravidelne rozrastal o povinné príspevky všetkých zamestnancov, ktoré boli stanovené ako platby v dvoch formách. Pri vstupe do zamestnania museli všetci pracovníci (vrátane tovarišov) z prvej výplaty nenávratne vložit' jeden zlatý k. m. ${ }^{77}$ a potom

76 Statuten des Kranken Fonds und Namens Verzeichniß der theilhabenten (!) Mitglieder. SNA, fond Zay - Súkenka, Nemocenský fond - účtovné knihy, účty, roky 1847 - 1873, k. 598.

77 Pri opätovnom vstupe do zamestnania sa vkladala polovica uvedenej sumy. Učni museli zlo- 
každý týždeň odvádzali 6 grajciarov k. m. Znížený príspevok sa očakával aj od rekonvalescentov, ktorí boli už schopní vykonávat' l'ahšie (platené) práce. Platobnú disciplínu mala zabezpečovat' hrozba pokuty v prípade omeškanej platby, v podobe dvojnásobnej výšky povinného týždenného príspevku.

Vd’aka racionálne nastavenému systému príjmov nasporená suma od doby vzniku fondu za tri mesiace (do konca januára 1848) dosiahla 553 zl. 12 gr. k. m. a pri d’alšej revízii 18. októbra 1848 vykazovala 936 zl. 14 gr. k. m. Čast' nasporenej sumy sa pravidelne vkladala do fondu fabriky, ktorý sa d’alej zhodnocoval prostredníctvom vkladu do sporitel'ne. K 18. októbru 1848 sa takto uložilo 500 zl. k. m., k 31. decembru 1849 síce len 300 zl. k. m., ale k 31. decembru 1850 opät' 400 zl. k. m. Ak by uložený kapitál, resp. z neho plynúce úroky boli dostatočne vysoké, mohli sa týždenné príspevky zamestnancov prípadne znížit' alebo aj zrušit', k takejto situácii však nedošlo.

Narábanie s peniazmi podliehalo nielen bežnej účtovnej kontrole, ale aj dohl'adu celého osadenstva. Pokladnicu a jej účtovnú knihu spravoval jeden zamestnanec kancelárie fabriky a traja členovia „osadenstva“, vedenie však vykonávalo priebežnú kontrolu. Každý štvrt'rok sa všetkým zamestnancom oznamoval stav konta pokladnice a narábanie s ním. Zamestnanci sa mohli presvedčit', že z fondu sa poskytujú príspevky chorým robotníkom, a to dokonca aj po dobu viacerých týždňov. Fond teda skutočne poskytoval reálnu oporu (denne 25 gr. k. m., k tomu navyše aj bezplatné lekárske ošetrenie a lieky) tým, ktorí kvôli chorobe neboli schopní práce. Priemerná doba čerpania podpory počas choroby bola v priebehu prvých troch rokov (do 31. decembra 1848) 4,14 dňa. Za týmto číslom sa skrýva celkový počet 219 chorých, ktorí „odmaródovali“ 1127 dní - aj tento priemer však stiera napr. údaj o podpore dlhodobo, až pät’ týždňov chorého Franza Thomasa či štyri týždne sa liečiaceho Johanna Hnateka. Poistenci sa aj v prípade úmrtia mohli spol'ahnút' na primerané zaopatrenie (príspevok na pohreb vo výške 4 zl. k. m., možnost' priplatit' na zvonenie), čo nebolo bez významu najmä pre „,ezpol'ných“ robotníkov či robotníčky. Ani bez priamej či rýchlej podpory rodiny tak neboli vydaní napospas nedôstojnému pochovaniu.

\section{Záver}

Súkenka v Uhrovci predstavovala modernú továreň, ktorá sa zaradila medzi celouhorsky významné podniky svojho druhu. Napriek tomu bola len okrajovo spomínaným podnikom, ktorý sa oprávnene dá charakterizovat' ako príklad podnikatel’ského zámeru „na zelenej lúke“, v regióne, kde boli k dispozícii len minimálne materiálne (produkcia vlny) a žiadne infraštruktúrne predpoklady (komunikačná siet', mestské centrá). Jej úspech však generoval d’alšie podnika-

žit’ po prepustení z učenia jednorazovo 2 zl. k. m. 
tel'ské zámery. Samotný zakladatel' Karol Zay začal už po roku existencie súkenky pripravovat' založenie sklárne a cukrovaru v blízkych Podlužanoch. ${ }^{78}$ Projekt mal pritom aj inú komparatívnu prednost’ - silný vstupný kapitál, ktorým disponoval výlučne majitel'. Nemenej významný bol aj sociálny kapitál, ktorý sa na neho viazal. Bohatý aristokrat mal množstvo konexií, ktoré mu umožnili úspešné etablovanie v hospodárskom priestore (Horného) Uhorska. Sám majitel' získaval pre fabriku investorov a zákazníkov medzi svojimi aristokratickými priatel'mi a známymi a návšteva prešporského obchodu patrila medzi jeho každodennú rutinu počas pobytov v meste. Gróf Karol Zay bol pred rokom 1848 stúpencom liberalizmu nielen vo vzt’ahu k politickému usporiadaniu Uhorska, ale najmä čo sa týkalo jeho ekonomického vývoja. Aktívne podporoval aj iné progresívne podujatia (stavba železnice) a dokázal nadväzovat' dobré vzt'ahy so stabilnými zákazníkmi - najmä z radov armády a žandarmérie. Štátne objednávky však predstavovali zároveň rizikový faktor vo forme nerealisticky nastavených podmienok zo strany odberatel'ov, ktoré začali postupne ohrozovat' rentabilitu podniku. Fabrika pracovala až do 70. rokov 19. storočia, ked' boli Zayovci donútení (už po smrti svojho otca - zakladatel'a podniku) predat' ju. V priestoroch súkenky našla svoje miesto výroba skla, čím sa začala nová etapa podnikania v Uhrovci.

* Štúdia vznikla v rámci projektu APVV-15-0349 Indivíduum a spoločnost’ - ich vzájomná reflexia $v$ historickom procese.

\section{UNTERNEHMERTÄTIGKEIT IN DER REGIE EINES ARISTOKRATEN: GRÜNDUNG UND ERSTE JAHRE DER TUCHFABRIK IN UHROVEC (1845-1851)}

\section{EVA K OWA L S K Á}

Die (Fein)Tuchfabrik in Uhrrovec ist ein bisher unbekanntes, aber doch ausreichend aussagekräftiges Beispiel für die Errichtung einer Fabrik ,auf der grünen Wiese“. Sie entstand in einer Region, die dazu keine ausreichenden materiellen und infrastrukturellen Voraussetzungen hatte. Das Projekt hatte jedoch einen anderen komparativen Vorteil - ein starkes Kapital, über das der Eigentümer, ein wohlhabender Aristokrat mit Beziehungen, die ihm eine erfolgreiche Etablierung im wirtschaftlichen Bereich von (Ober)Ungarn ermöglichten, verfügte. Der Graf Karol Zay war ein Anhänger des Liberalismus nicht nur in Bezug auf die politische Anordnung von Ungarn vor 1848, sondern auch auf seine wirtschaftliche Entwicklung. Er hat auch andere progressive Geschäftsabsichten (Eisenbahnbau, Dampfschifffahrt) unterstützt und war in der Lage,

78 Denník K. Zayho z 2. 3. 1846. SNA, fond Zay - Karol Zay, Mária Kollowrat (denník), k. 220. 
eine Geschäftsbeziehung mit einem stabilen Kunden - Armee und Gendarmerie - aufzunehmen.

Die Studie analysiert den Prozess des Aufbaus der Fabrik, finanzielle Seite des Baus und der Einrichtung, Fragen der Personal- und Materialfunktion, sowie die Fragen der sozialen Sicherheit der Arbeiter (ein bedeutender Teil von ihnen waren Frauen). Die Fabrik hatte mehrere Firmengeschäfte und ein Netz von Abnehmern in Ungarn. Während der Revolution begann sie aus den Lieferungen für die Armee, Militia Portalis und Gendarmerie zu profitieren. Die öffentlichen Aufträge haben jedoch gleichzeitig einen Risikofaktor in Form von unrealistisch eingestellten Bedingungen seitens der Abnehmer dargestellt, die allmählich die Rentabilität des Geschäfts zu gefährden begannen. Gleich am Anfang dieser Zusammenarbeit verzeichnete die Fabrik einen Verlust, der ihren Betrieb zu gefährden begann.

PhDr. Eva Kowalská, DrSc.,

Historický ústav SAV

Klemensova 19, 81499 Bratislava

e-mail: eva.kowalska@savba.sk 